\title{
NEW SPECIES AND NOMENCLATURAL NOTES IN PABSTIELLA (ORCHIDACEAE: PLEUROTHALLIDINAE) FROM BRAZIL
}

\author{
A. L. V. Toscano de Brito ${ }^{1,3} \&$ Carlyle A. Luer ${ }^{2}$ \\ ${ }^{1}$ Marie Selby Botanical Gardens, 811 South Palm Avenue, Sarasota, FL 34236-7726, U.S.A. \\ ${ }^{2}$ Missouri Botanical Garden, 2345 Tower Grove Avenue, St. Louis, Missouri 63110, U.S.A. \\ Corresponding address: 3222 Old Oak Drive, Sarasota, FL 34239-5019, U.S.A.
}

${ }^{3}$ Author for correspondence: atoscano@selby.org

\begin{abstract}
Two new species, Pabstiella calimanii and Pabstiella recurviloba, are described and illustrated. One new combination, Pabstiella deltoglossa, is proposed. Eight species and one variety are proposed as synonyms. They are listed in alphabetical order: Pabstiella avenacea, P. leucosepala and Pleurothallis mathildae as synonyms of Pabstiella elegantula; Pabstiella cipoensis as a synonym of P. pristeoglossa; Pleurothallis magnicalcarata and Pabstiella mentigera as synonyms of P. calcarata; Pabstiella pterophora and Pleurothallis pterophora var. minor as synonyms of Pabstiella leucopyramis, and Pabstiella podoglossa as a synonym of $P$. versicolor. Lectotypes are selected for four species: Pleurothallis avenacea, P. mentigera, P. pristeoglossa and P. pterophora. An epitype is selected for Pleurothallis pristeoglossa. Illustrations and taxonomic discussions are also provided.
\end{abstract}

KeY worDs: Brazilian Atlantic forest, synonyms, typifications

Introduction. The genus Pabstiella Brieger \& Senghas comprises about one hundred of mostly South American species, the majority restricted to the Atlantic forests of south-eastern Brazil. Molecular data (Chiron, Guiard \& van den Berg, 2012; Karremans, Bakker, Pupulin, Solano-Gómez \& Smulders, 2013) have demonstrated that the genus as circumscribed by Pridgeon and Chase (2001), Barros (2002), Pridgeon (2005), and Luer (2006), containing not more than six species, does not stand. These data have also shown that many species formerly classified in Pleurothallis R.Br. and Specklinia Lindl. and then transferred to Stelis Sw. by Pridgeon and Chase (2001) are in fact better included in Pabstiella. This corroborates with the expanded morphologically based circumscription of Pabstiella by Luer (2007). Recently, Chiron and van den Berg (2013) proposed to conserve the name Pabstiella against Phloeophila Hoehne \& Schltr. arguing that molecular data place the type of Phloeophila, $P$. paulensis Hoehne \& Schltr. [= P. nummularia (Rchb. f.) Garay], within the genus Pabstiella, and this would prevent transfer of all Pabstiella names to Phloeophila. The proposal to conserve Pabstiella was, however, not recommended by the Nomenclature Committee for Vascular Plants (Applequist, 2013). Fortunately, a transfer of all Pabstiella species to Phloeophila has not been proposed as this would have been not only premature and based on mistaken results, but it would not have contributed in any way to the understanding of this orchid group. A recent as yet unpublished analysis of nrITS data of the Pleurothallidinae (Toscano de Brito \& Smidt, unpubl. data) shows that Phloeophila nummularia is not embedded within Pabstiella. While the present paper was being reviewed, an article was published (Chyron et al. 2016) confirming that Phloeophila and Pabstiella are apparently not related and that the molecular information obtained by Chiron and van den Berg (2013) was based on misidentified material. We feel that authors should refrain from proposing massive nomenclatural changes based on only one DNA fragment, until a much broader sampling of the Pleurothallidinae is undertaken, and until morphological analyses coupled with analyses of additional DNA regions are carried out.

The World Checklist of Selected Plant Families (WCSP, accessed in January 2016) published online by the Royal Botanical Gardens, Kew, lists 79 accepted names, while 107 names are accepted in 
Lista de Espécies da Flora do Brasil (Barros, Vinhos, Rodrigues, Barberena, Fraga, Pessoa, Forster, Menini Neto, Furtado, Nardy, Azevedo \& Guimarães, 2016). After studying protologues and available type specimens of almost all Pabstiella species and their synonyms, it has become clear that several names have been consistently misidentified and confused in herbaria and literature. As currently accepted by the authors of the present article, Pabstiella consists of about 100 species (several new and as yet unpublished) distributed mainly in southern Brazil. This figure approaches that of Barros et al. (2016) for the Brazilian flora. A few species have wider distribution, occurring in Bolivia, Amazonian Brazil, Colombia, Ecuador, Peru and Venezuela, with two species reaching Panama and Costa Rica (Luer, 2006). In this article we describe and illustrate two new species of Pabstiella from Brazil and propose one new combination and nine new synonyms. Illustrations, updated synonym lists, taxonomic discussions and typifications are provided for several species.

\section{NEW SPECIES}

\section{Pabstiella calimanii Toscano \& Luer, sp. nov.}

TYPE: Brazil. Minas Gerais: Jacinto, collected and cultivated by Sávio Caliman, fl. cult. 6 June 2010, A. Toscano de Brito 3073 (holotype: MBM [306681]; isotype UPCB), C. Luer illustr. 21902. Fig. 1-2.

This species is similar to Pabstiella cordilabia (Pabst) Luer, but differs by the distinctly long-petiolate, convex, broader leaves; minutely pubescent sepals; and the narrower, obscurely trilobed, oblong lip.

Plant medium in size, ca. $1.0 \mathrm{~cm}$ tall, epiphytic, caespitose; roots slender. Ramicauls erect 2.5-4.0 $\mathrm{cm}$ long, enclosed by a tubular, red-brown sheath from near the base to the middle and another sheath near the base. Leaf erect, rigid, coriaceous, broadly spathulate-elliptical, convex, $5.0-5.5 \mathrm{~cm}$ long with the petiole $1.5-2.0 \mathrm{~cm}$ long, $2.2-2.7 \mathrm{~cm}$ wide, obtuse to acute at the minutely 3 -denticulate apex, distinctly cuneate below into a channeled, occasionally slightly twisted petiole. Inflorescence 1-2 sublax, successively, several-flowered racemes with ca. 4 flowers, usually shorter or barely surpassing the leaf, usually with two simultaneously open flowers, $3.0-4.0 \mathrm{~cm}$ long including the peduncle $2.0-2.5 \mathrm{~cm}$ long, borne laterally from the ramicaul below the abscission layer with a thin spathe $2.0 \mathrm{~mm}$ long; floral bracts 2.0-3.0 mm long; pedicels 4.0-5.0 $\mathrm{mm}$ long; ovary $2.0 \mathrm{~mm}$ long; sepals dull yellow to yellow-orange, densely spotted and suffused with red-purple, glabrous externally, minutely pubescent internally, the dorsal sepal oblong-obovate, obtuse, carinate externally along the mid-vein, the basal two thirds concave, the apical third convex and slightly recurved, 7.0-7.5 mm long, 2.8-3.0 mm wide, 3-veined, the lateral sepals connate to near the apex into an oblong, concave, externally bicarinate, shortly bifid synsepal with acute, minutely apiculate tips, 6.5-7.0 $\mathrm{mm}$ long, 3.5-4.0 $\mathrm{mm}$ wide expanded, incompletely 6-7-veined; petals densely spotted with red-purple over a dull greenish-yellow background, obliquely obovate, narrowed below, minutely verrucose externally, glabrous, obtuse, $3.5 \mathrm{~mm}$ long, 1.75-2.0 mm wide, incompletely 2-veined; lip yellow, spotted with red-purple, papillar-verrucose, oblongtrilobed, $4.0 \mathrm{~mm}$ long, $1.0 \mathrm{~mm}$ wide unexpanded, the apical third slightly convex, oblong-ovate, obtuse, the lateral lobes below the middle, obscure, erect, low, rounded, the disc with a pair of parallel, erect, submarginal, longitudinal calli, broadly channeled between the calli, the base truncate, with an indistinct lobule at each corner, hinged to the column-foot; column yellow, edged in red-purple, slender, semiterete, tridentade with denticulate margins at apex, 3.0-3.5 mm long, the anther, rostellum, and stigma ventral, the foot thick and shallowly concave, $1 \mathrm{~mm}$ long.

Distribution: So far, this species is only known for the municipality of Jacinto, state of Minas Gerais, southeastern Brazil.

Etymology: The specific epithet honors Sávio Caliman from Venda Nova do Imigrante, Espírito Santo, Brazil, who collected and cultivated this species.

Pabstiella calimanii resembles $P$. cordilabia (Fig. 3) in floral color and shape of floral segments, especially sepals and petals. However, Pabstiella calimanii is distinguished by cuneate-petiolate, 
E
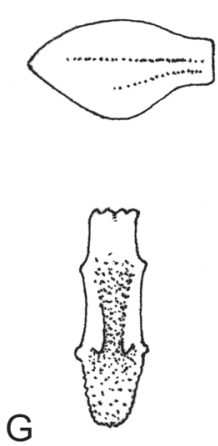

C
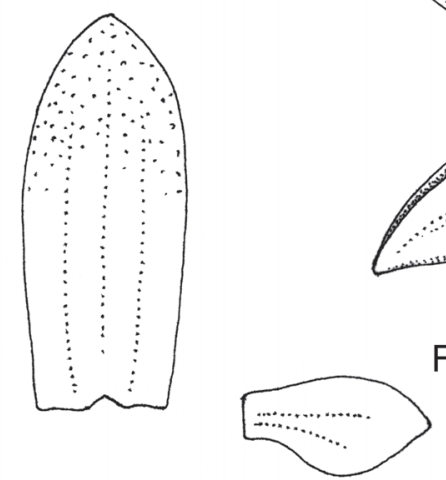

$F$
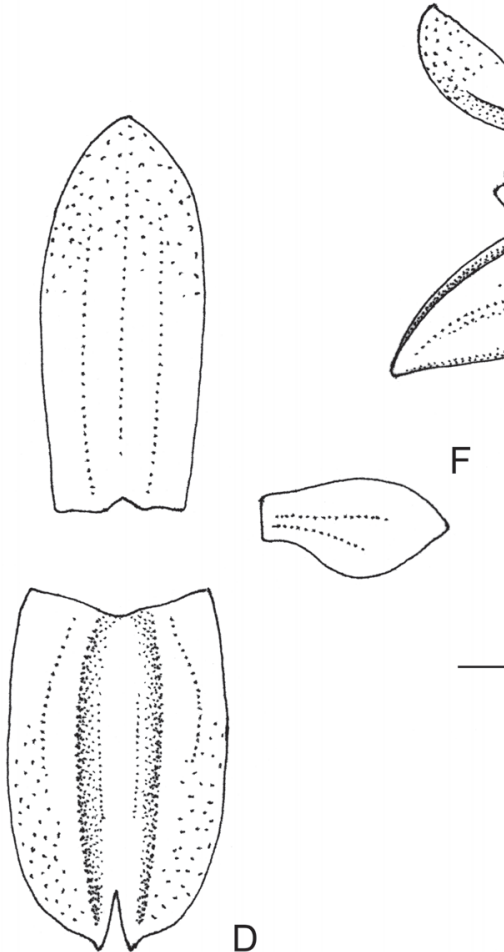
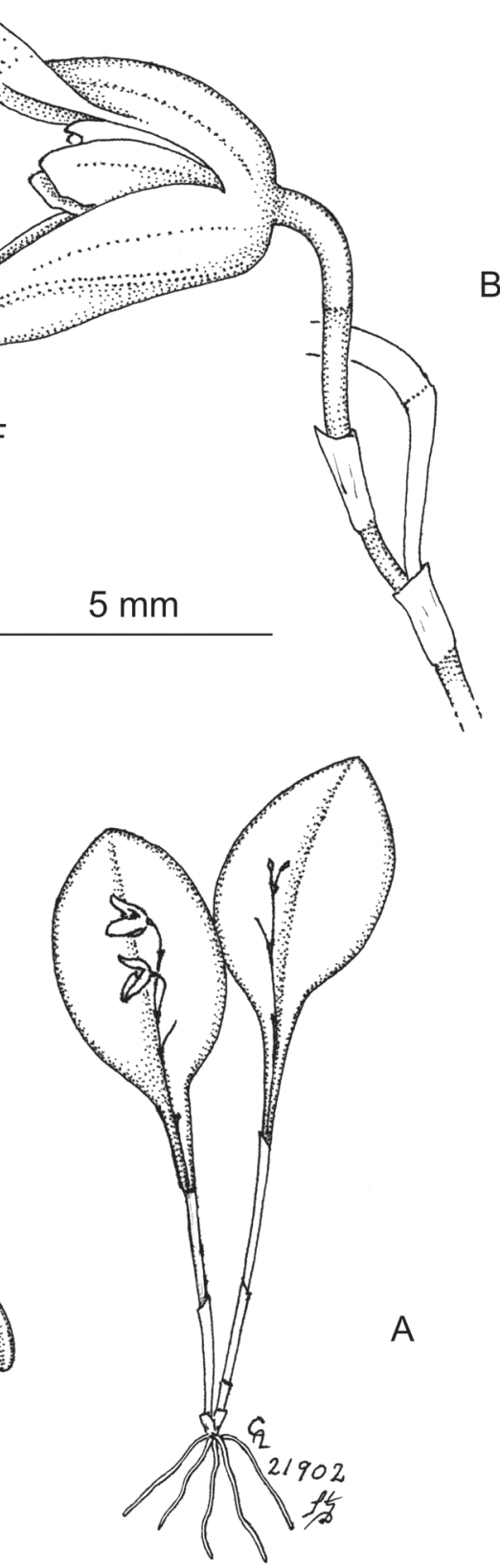

$5 \mathrm{~cm}$

Figure 1. Pabstiella calimanii. A - Habit; B - Apical portion of inflorescence with a flower, side view; C - Dorsal sepal;

D - Synsepal; E-F - Petals; G-H - Lip; I - Ovary, column and lip, side view. Drawn by C.A. Luer based on the isotype (A. Toscano de Brito 3073, UPCB).

convex, broader elliptical leaves, minutely pubescent sepals, and a narrower, obscurely trilobed, oblong lip, instead of much narrower and flat leaves, glabrous or only microscopically papillose sepals, and a lip with distinct, erect, broadly rounded, lateral lobes, which, when expanded, render a cordate outline. 


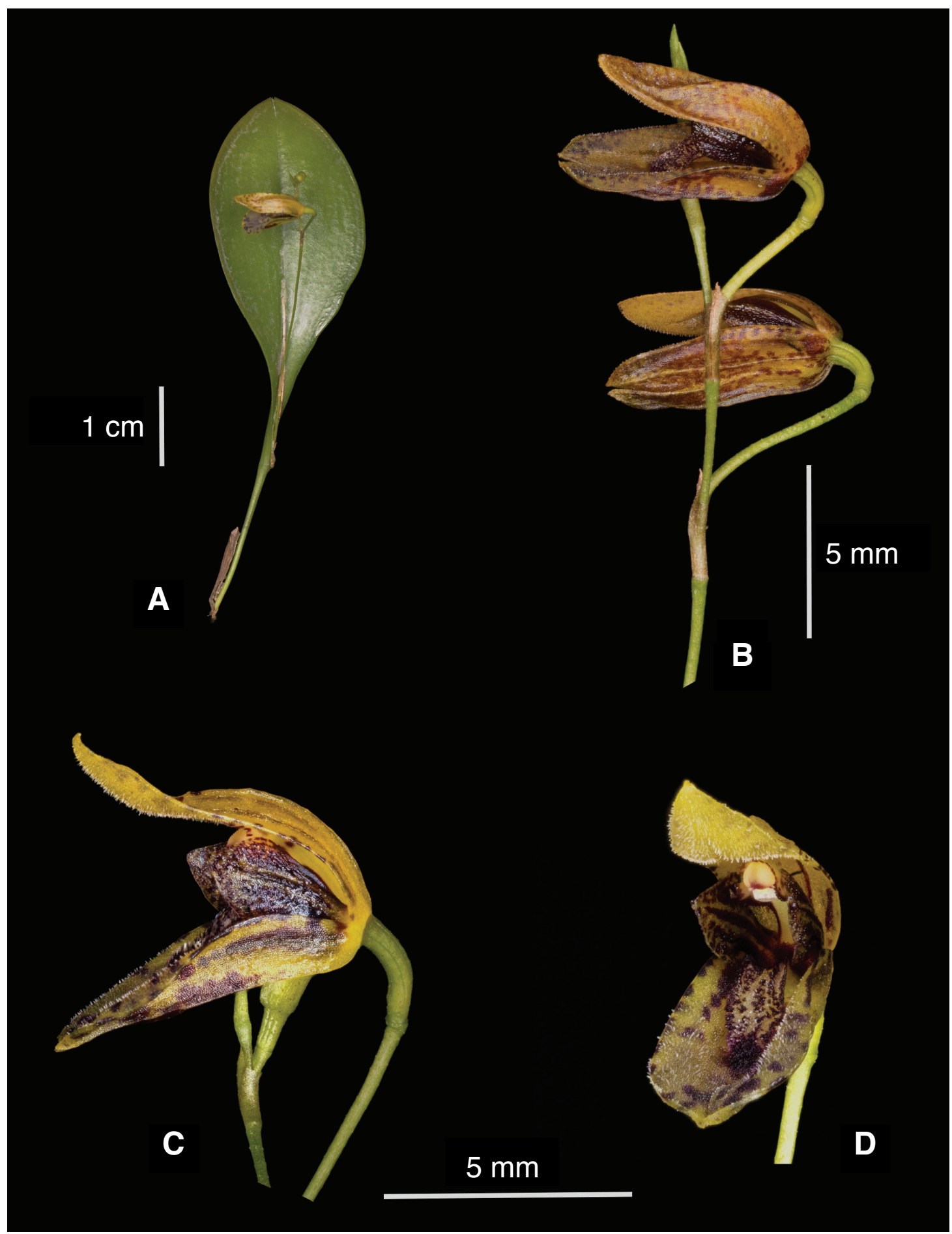

Figure 2. Pabstiella calimanii. A - Portion of ramicaul, leaf and inflorescence; B - Apical portion of inflorescence; C Flower, side view; D - Flower, $3 / 4$ view. Based on a clone of the holotype (A. Toscano de Brito 3073). Photograph by W. Collier \& A. Toscano de Brito. 


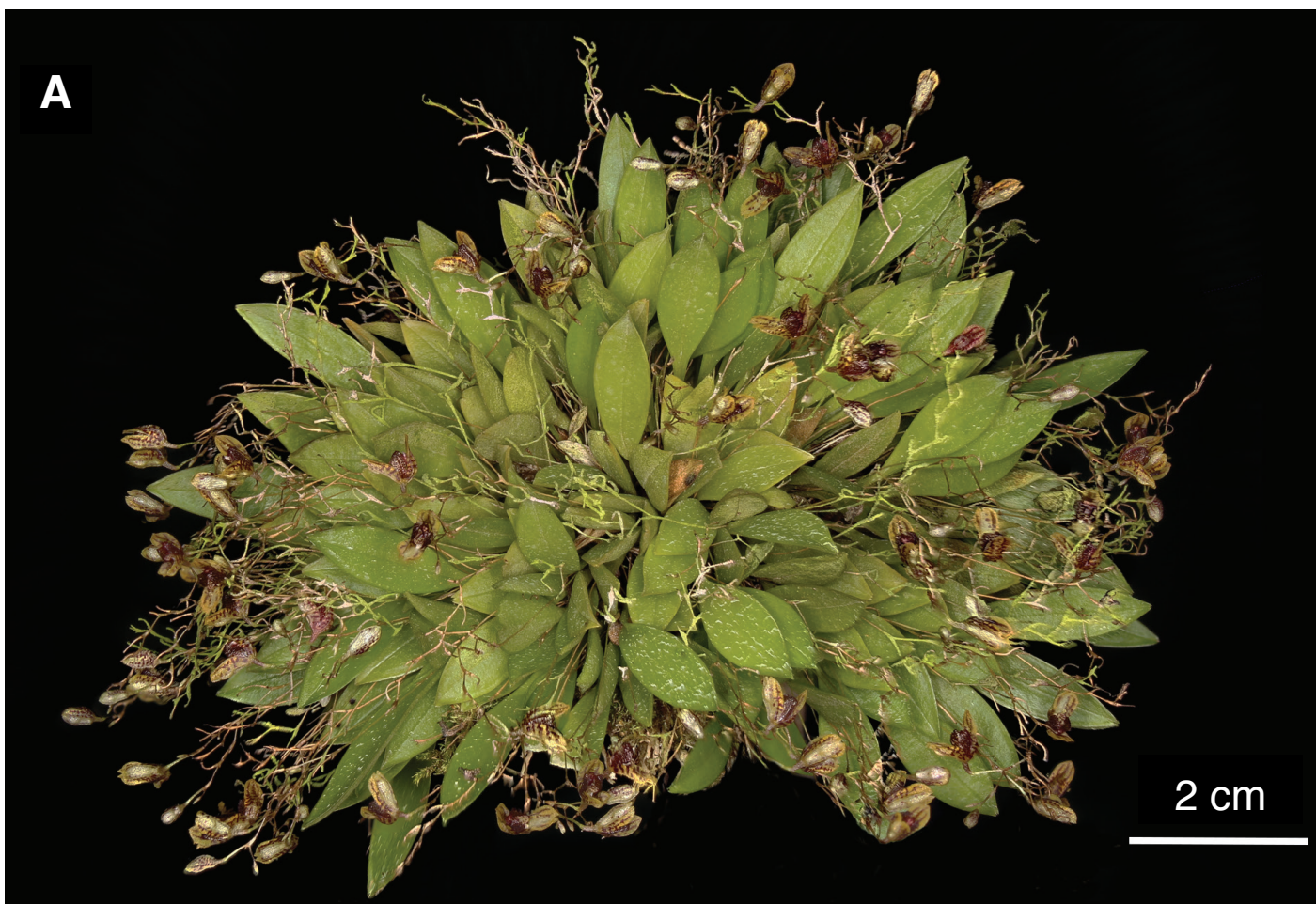

B

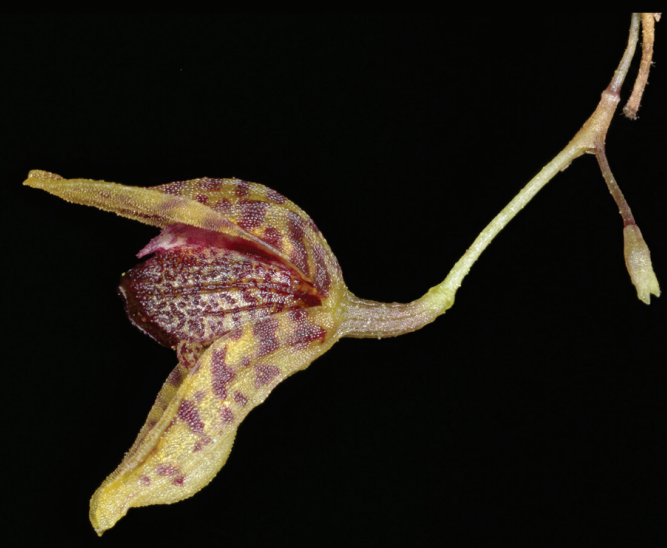

$5 \mathrm{~mm}$

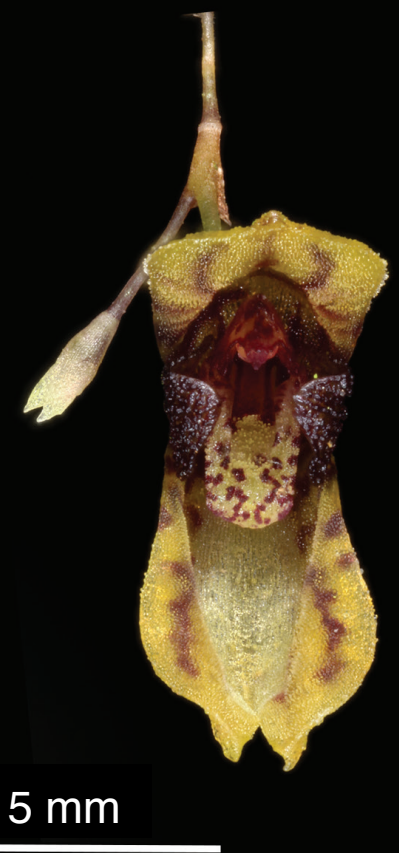

C

Figure 3. Pabstiella cordilabia. A - Habit; B - Apical portion of inflorescence with flower in side view; C - Flower, front view. Based on A. Toscano de Brito 3484 (UPCB). Photograph by W. Collier \& A. Toscano de Brito. 
Pabstiella recurviloba Toscano \& Luer, spec. nov.

TYPE: Brazil. Paraná: São José dos Pinhais, Represa do Vossoroca, ca. 800 m, collected 21 July 2010, fl. cult. 2 Nov. 2010, A. Toscano de Brito \& M. Klingelfus 3331 (holotype: MBM [334253]). C. Luer Illustr. 21904. Fig. 4-5.

This species is similar to Pabstiella verboonenii Luer \& Toscano, from which it differs by its narrower, linear-ensiform petals and the distinctly trilobed lip.

Plant small, up to ca. $4.5 \mathrm{~cm}$ tall excluding the inflorescence, epiphytic, densely caespitose, roots slender. Ramicauls slender, erect, 15.0-35.0 mm long, enclosed by $2-3$ closely appressed, microscopically pubescent, tubular sheaths with minutely scabrous, thickened and dilated ostia. Leaf green, densely speckled with purple, coriaceous, broadly elliptical, obtuse to subacute, minutely apiculate, $7.0-13.0 \mathrm{~mm}$ long including a petiole $1.0-4.0 \mathrm{~mm}$ long, 5.0-7.0 $\mathrm{mm}$ wide, broadly cuneate below into the petiole. Inflorescence a loose, flexuous, successively severalflowered raceme of up to ca. 18 flowers, up to $8.5 \mathrm{~cm}$ long including the peduncle $3.0-4.0 \mathrm{~cm}$ long, from near the apex of the ramicaul; floral bracts $1.2-1.5$ $\mathrm{mm}$ long; pedicels $1.5-2.5 \mathrm{~mm}$ long; ovary $1.0-1.5$ $\mathrm{mm}$ long; flowers resupinate or non-resupinate; sepals glabrous, the dorsal sepal dark purple, the apical third greenish, narrowly ovate-elliptical, $5.0 \mathrm{~mm}$ long, 1.0 $\mathrm{mm}$ wide, 3-veined, with the apex deeply cucullate, obtuse, the lateral sepals dark purple, connate to near the apex into an oblong-obovate, cymbiform, shortly bifid lamina with acute tips, $4.0 \mathrm{~mm}$ long, $3.0 \mathrm{~mm}$ wide unexpanded, 6-veined; petals dark purple, entire, linear-ensiform, acute, $2.0-2.2 \mathrm{~mm}$ long, 0.5-0.7 $\mathrm{mm}$ wide, 1-veined; lip dark purple, oblong-trilobed, $2.2 \mathrm{~mm}$ long, $0.7 \mathrm{~mm}$ across unexpanded, shallowly concave between the lateral lobes, the middle lobe broadly ovate, convex, fleshy, with the apex rounded, the lateral lobes near the middle, obliquely triangular, erect, recurved, slightly incurved, obtuse, $0.6 \mathrm{~mm}$ long, $0.5 \mathrm{~mm}$ wide, the disc with a pair of oblique calli from the bases of the lateral lobes, the basal third unguiculate, curved, slightly convex, minutely pappilose, the base truncate, hinged to the column-foot; column slender, cylindrical, toothed at apex, $2.0 \mathrm{~mm}$ long, the anther, rostellum, and stigma ventral, the foot slender, $0.5 \mathrm{~mm}$ long.
Additional material eXAmined: Brazil. Rio Grande do Sul. São Francisco de Paula, Canyon do Josafá, 950 m, collected and cultivated by J. Klein and L.F. Varella 227, fl. cult. 27 Nov. 2014, A. Toscano de Brito 3323 (UPCB). Distribution: So far, this species is only known for the states of Paraná and Rio Grande do Sul, southern Brazil.

Eтymology: From the Latin recurvilobus (= recurved lobe), in reference to the recurved, lateral lobes of the lip.

Pabstiella recurviloba is similar to Pabstiella verboonenii in habit, inflorescence, and floral morphology. They share similar delicate ramicauls, which are covered with pseudo-lepanthiform sheaths. They also have similarly purple-speckled, small, elliptical leaves, and flowers produced successively in a loose, flexuous, long-pedunculated raceme, which usually exceeds the leaf severalfold. Sepal morphology is also similar in both species, i.e., the lateral sepals are connate into a cymbiform, shortly bifid apex, and the apex of the dorsal sepal is characteristically hollow and thimble-like resembling the apex of the dorsal sepals of two species in the genus Specklinia Lindl., namely $S$. digitalis (Luer) Pridgeon \& M.W.Chase and S. segregatifolia (Ames \& C. Schweinf.) Solano $\&$ Soto Arenas. Nonetheless, $P$. recurviloba is readily distinguished from all these species by its narrower, linear-ensiform petals and the distinctly trilobed lip whose obliquely triangular, erect, recurved lateral lobes each resemble the dorsal fin of a shark in side view.

Pabstiella calcarata (Cogn.) Luer, Monogr. Syst. Bot. Missouri Bot. Gard. 112: 119. 2007. Fig. 6-9.

Basyonym: Pleurothallis calcarata Cogn., Bull. Soc. Roy. Bot. Belgique 43: 311.1906 (publ. 1907). TYPE: BRAZIL. Rio de Janeiro: without locality, A. Glaziou s.n. (Holotype: BR [658570]).

Synonyms: Specklinia calcarata (Cogn.) Luer, Monogr. Syst. Bot. Missouri Bot. Gard. 95: 259. 2004.

Pleurothallis mentigera Kraenzl., Kongl. Svenska Vetensk. Acad. Handl., n.s., 46(10): 50. 1911, syn. nov. TYPE: BRAZIL. Paraná: Roça Nova, Banhado, 30 December 1908, P. Dusén 7433 (holotype: B [destroyed]; lectotype here designated: S [S-R4966, photo seen]; isolectotypes: AMES [118455], HBG [501892, photo seen]). 


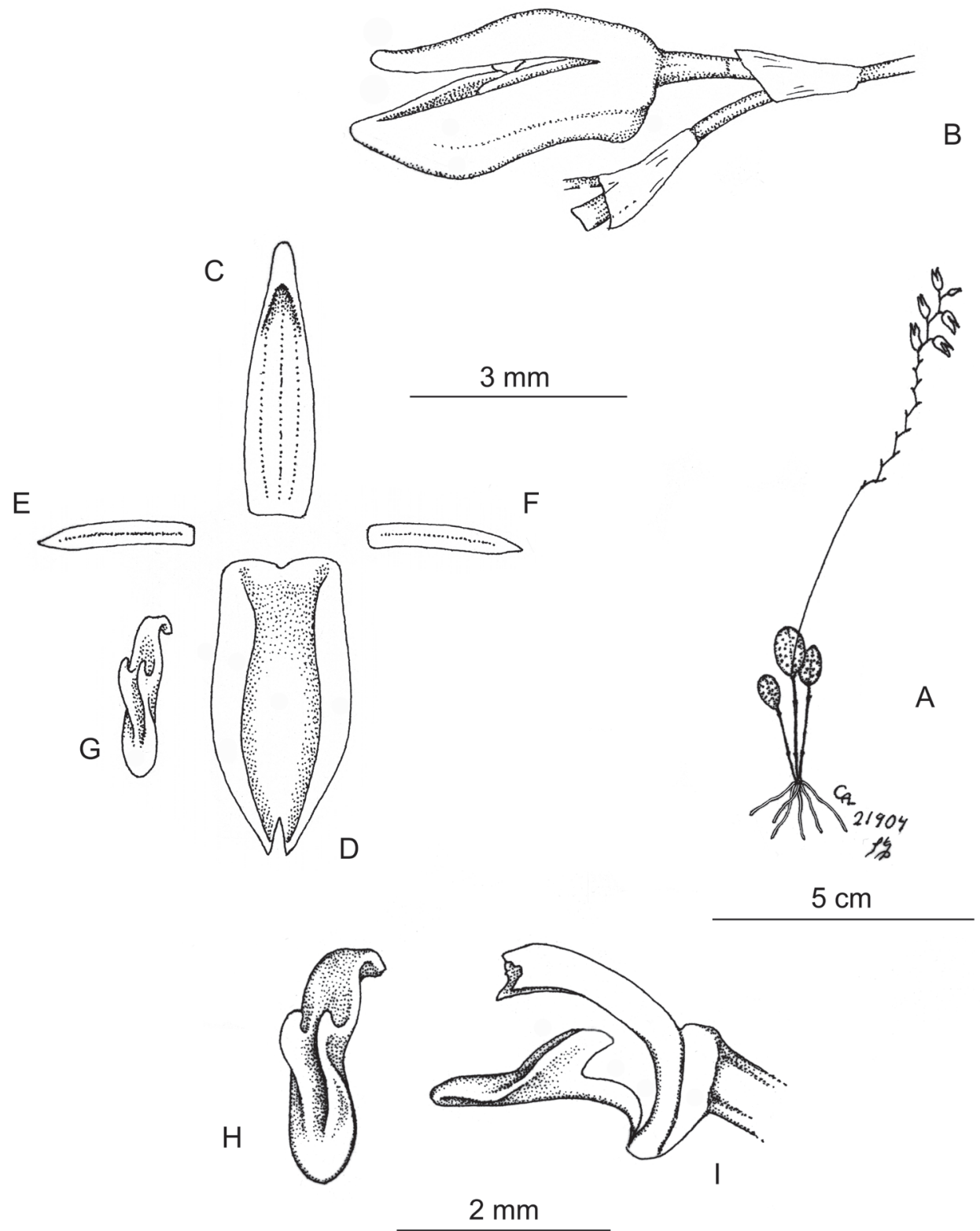

FiguRe 4. Pabstiella recurviloba. A - Habit; B - Portion of inflorescence with flower in side view; C - Dorsal sepal; D Synsepal; E-F - Petals; G-H - Lip; I - Portion of ovary, column and lip, side view. Drawn by C. A. Luer based on the holotype (A. Toscano de Brito \& M. Klingelfus 3331, MBM).

Pleurothallis magnicalcarata Loefgr., Arch. Jard. Bot. Rio de Janeiro 2: 51. 1918, syn. nov. TYPE: BRAZIL. São Paulo: Guaratinguetá, 1916, $P$. Campos Porto s.n. (holotype: RB [8285]; isotype: AMES [16292]).

Specklinia mentigera (Kraenzl.) F.Barros \& Barbarena, Rodriguésia 61(1): 130. 2010, syn. nov.
Pabstiella mentigera (Kraenzl.) L.Kollmann, Candollea 65: 96. 2010, syn. nov.

Pleurothallis calcarata Cogn. $[=$ Pabstiella calcarata (Cogn.) Luer] was described based on a specimen collected by Auguste Glaziou (1828-1906) in Rio de Janeiro. The protologue of P. calcarata 

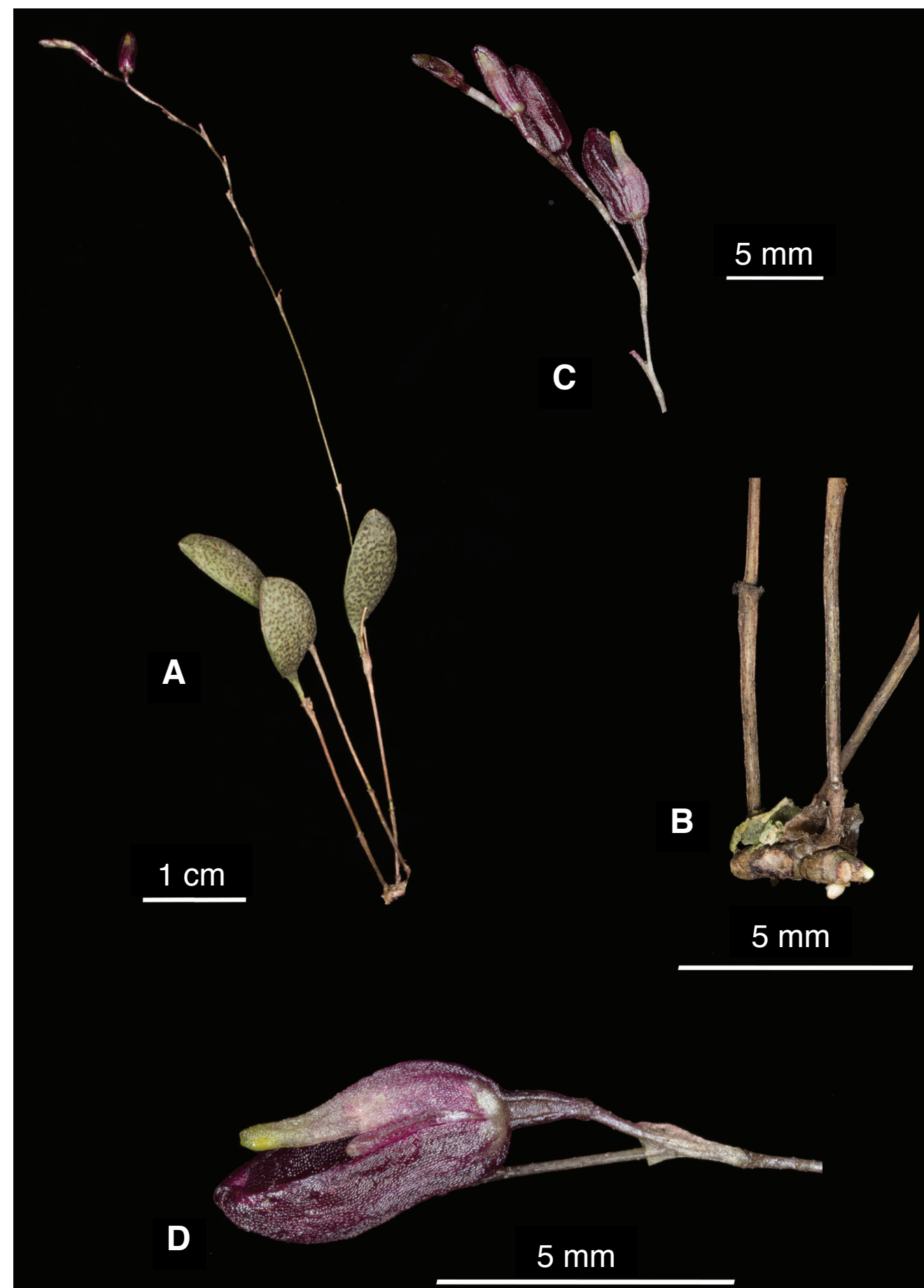

Figure 5. Pabstiella recurviloba. A - Habit; B - Basal portion of ramicauls showing rhizome and pseudo-lepanthiform sheath; C - Apical portion of a successively several-flowered raceme; D - Portion of inflorescence with flower in side view. Based on a clone of the holotype specimen (A. Toscano de Brito \& M. Klingelfus 3331). Photograph by W. Collier \& A. Toscano de Brito. 


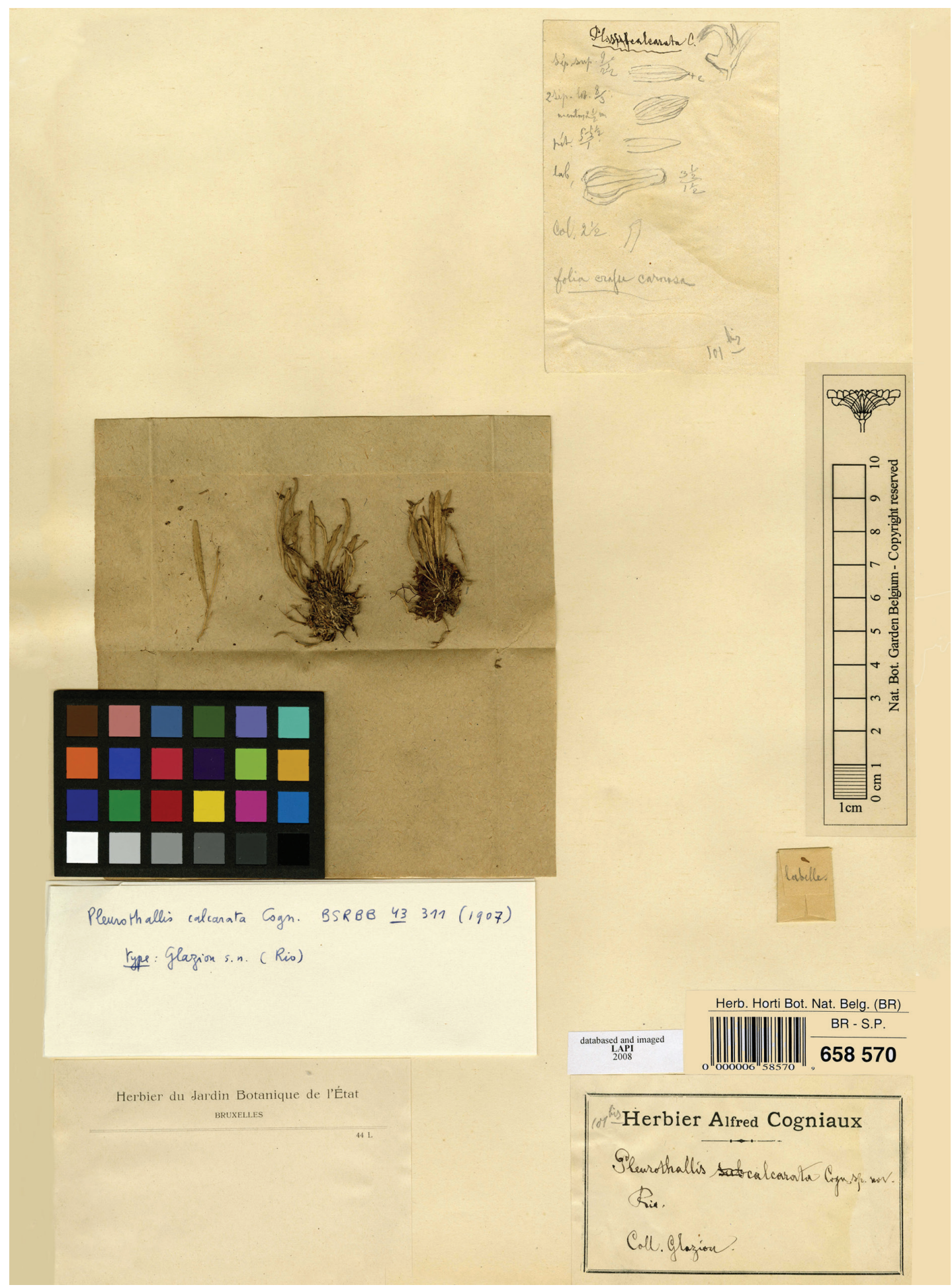

FIgure 6. Pabstiella calcarata. Holotype of Pleurothallis calcarata Cogn. deposited at BR. Reproduced with permission. Copyright: Jardin Botanique Meise. 


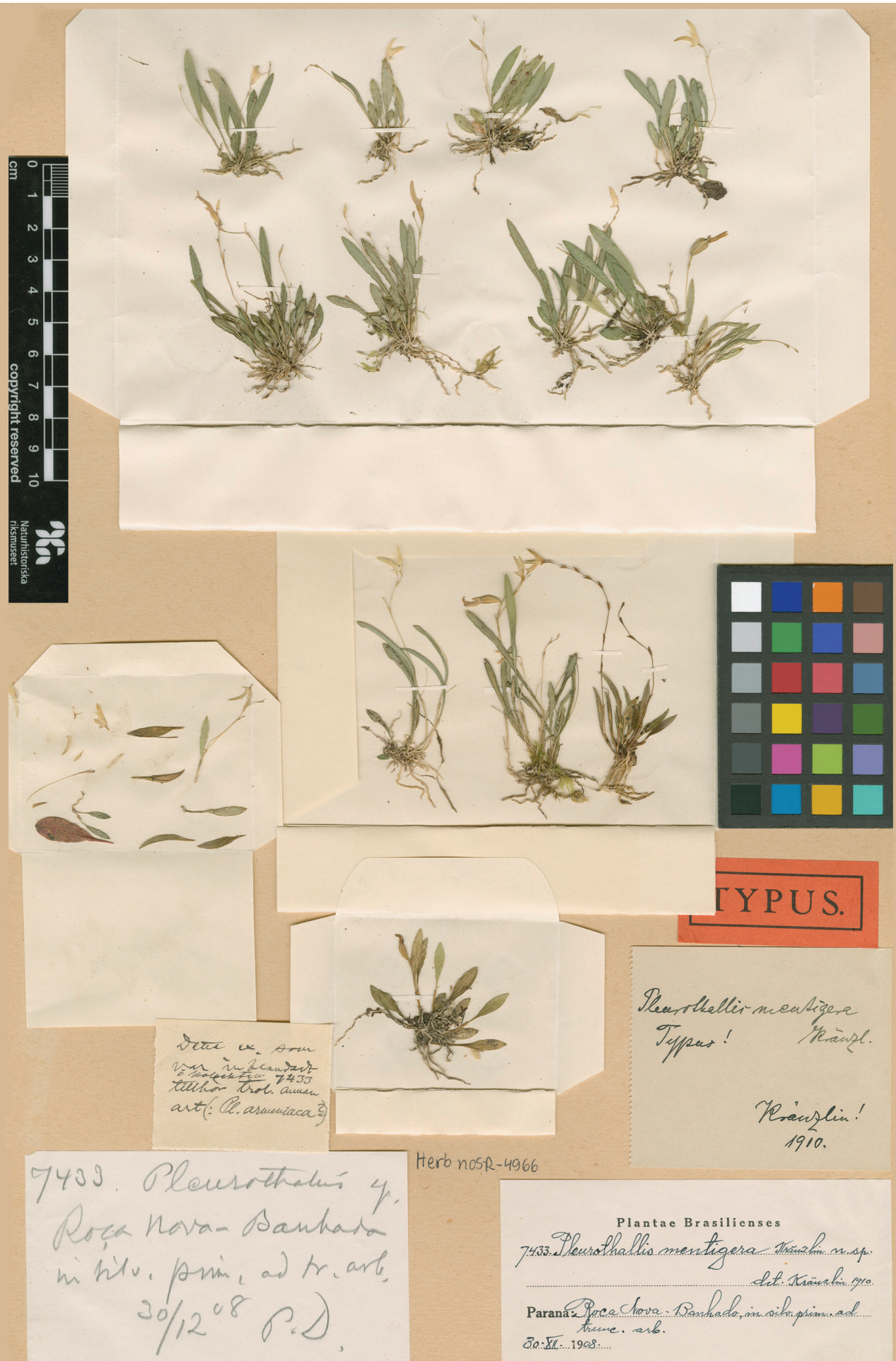

Figure 7. Pabstiella calcarata. Lectotype of Pleurothallis mentigera, here designated: P. Dusén 7433 (S-R-4966). By permission of the Keeper, Herbarium of the Swedish Museum of Natural History. 


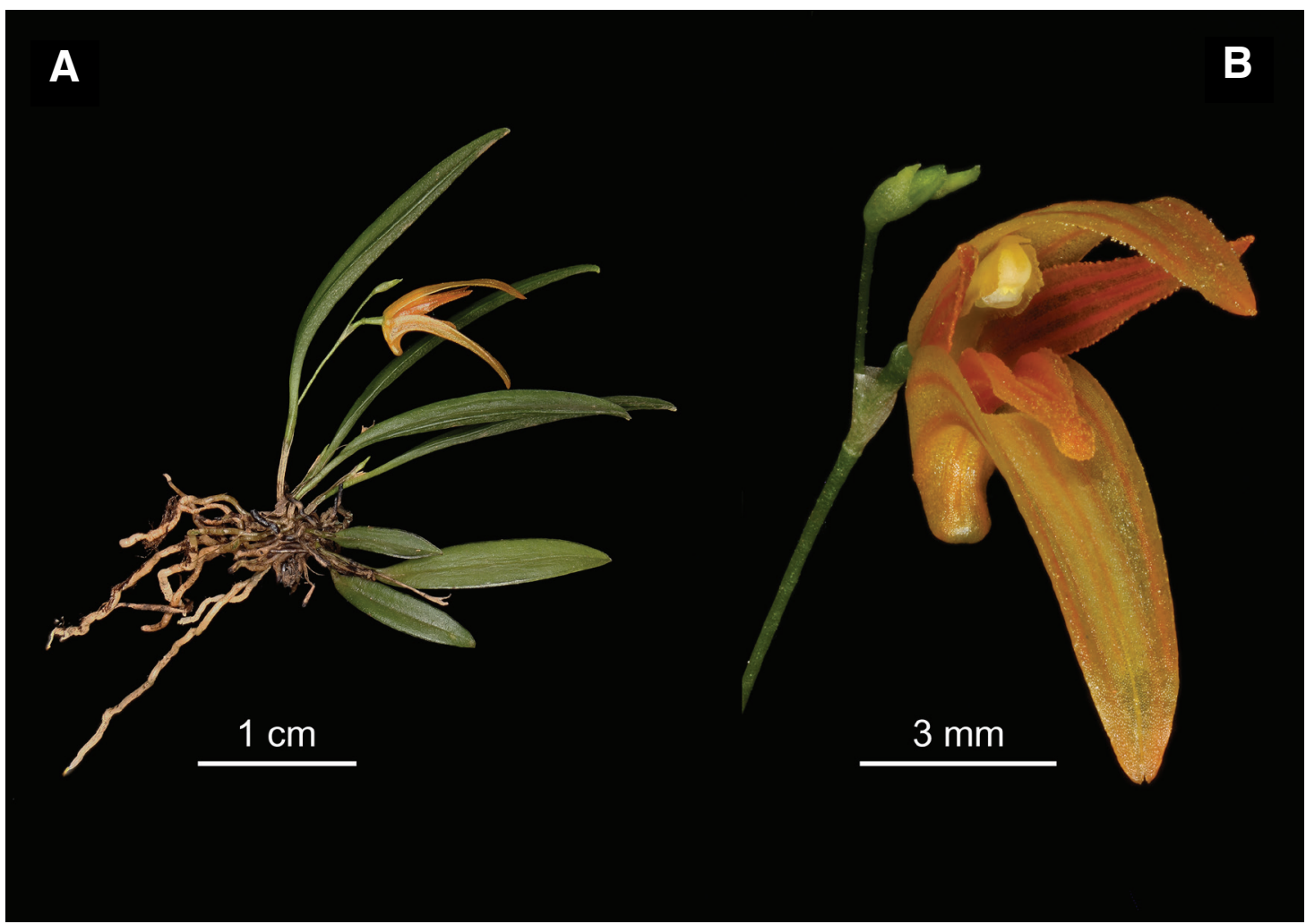

Figure 8. Pabstiella calcarata. A - Habit; B - Flower, 3/4 view. Based on A. Toscano de Brito 3470 (UPCB). Photograph by W. Collier \& A. Toscano de Brito.

contains a detailed description, but lacks an illustration. The lateral sepals were described as forming a spread calcar and the lip as sessile. The holotype deposited at BR (Fig. 6) contains two small specimens kept in an envelope, of which only one is fertile and carries a sole flower. To prevent damage to the more than a century old and only flower left, we did not dissect it. Glued on the upper right side of the sheet, a sketch, presumably prepared by Cogniaux, shows dissected floral parts and a flower in side view. The drawing clearly depicts a spurred flower and a sessile lip just as Cogniaux described. The lip on this sketch is a perfect match to the lip kept in a smaller envelope located at the lower, right portion of the herbarium sheet. A closer examination of this lip, however, reveals that it is apparently damaged at base and might most certainly have had a distinctive claw similar to the one found on the lip of Pleurothallis magnicalcarata Loefgr. and Pleurothallis mentigera Kraenzl. The lip claw on the type of Pleurothallis calcarata might have been damaged prior to Cogniaux's study, which would explain his description and illustration of a "sessile" lip of $P$. calcarata. The rest of the lip, however, agrees in every detail with lips from flowers of collections of P. mentigera and P. magnicalcarata, including their type specimens and the descriptions in the protologues. Habit, inflorescence, and the other floral segments are also a good match. Therefore, we conclude that these taxa are all conspecific. Pleurothallis mentigera and $P$. magnicalcarata are for this reason here placed in the synonym of Pabstiella calcarata. The type specimen of $P$. calcarata at BR bears number " 101 bis," but this number is not cited in the protologue.

The holotype of Pleurothallis mentigera Kraenzl. was most probably deposited at B and was destroyed during World War II (Christenson 1994). Isotypes exist at S, AMES and HBG. The specimen at S (Fig. 7) has been here selected as lectotype.

Pabstiella calcarata is distinguished by a deep spur that is exceeded by the spur of four other species: Pabstiella conspersa (Hoehne) Luer, P. mirabilis (Schltr.) Brieger \& Senghas, Pabstiella rupicola 


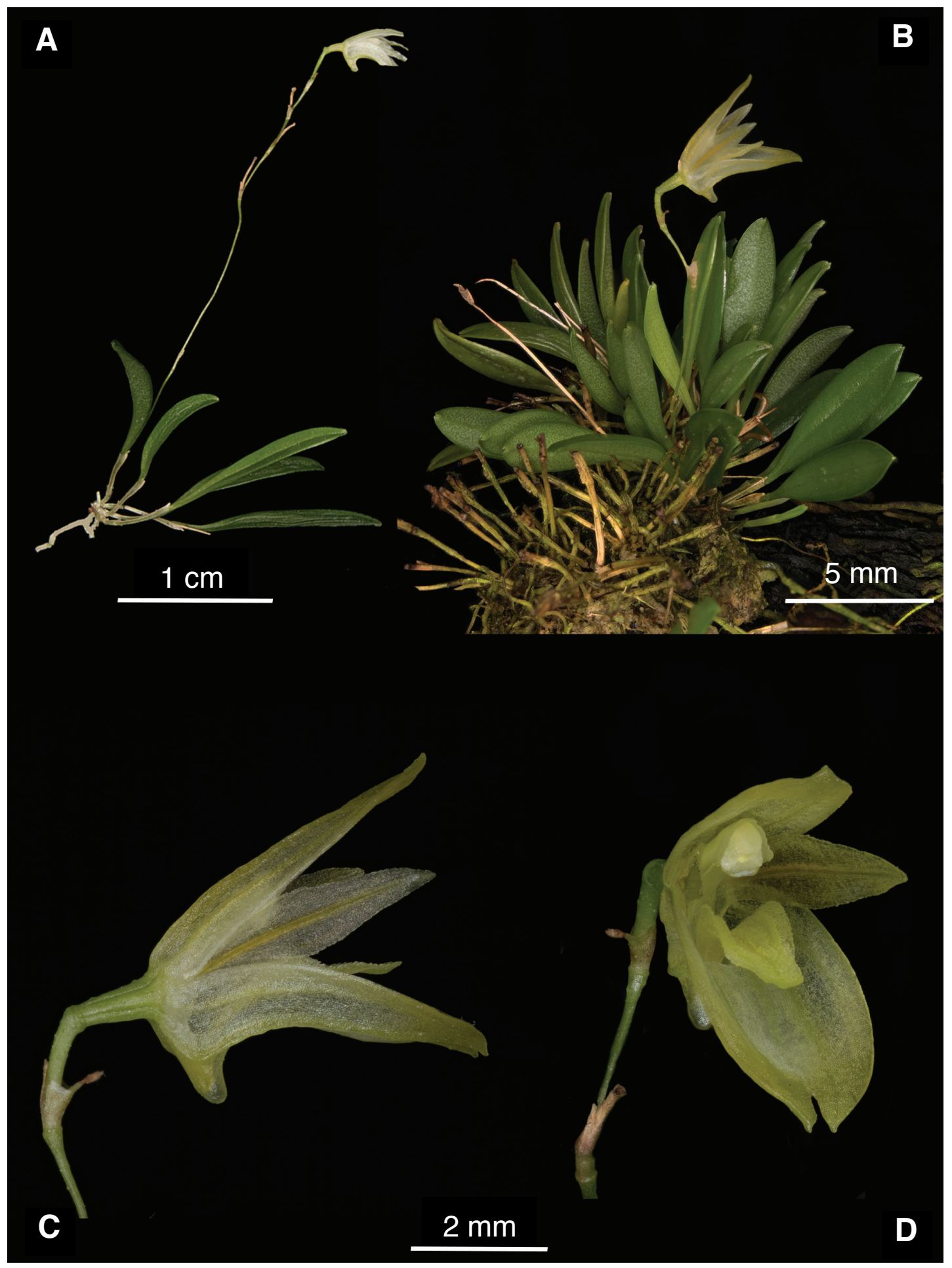

Figure 9. Pabstiella calcarata. A-B - Habit; C - Flower, side view; D - Flower, 3/4 view. A - based on A. Toscano de Brito 3553 (UPCB); B-D - based on A. Toscano de Brito 3351 (UPCB). 
L. Kollmann, and P. syringodes (Luer) F. Barros. Flower color varies from green, cream, yellow, dull orange to brownish. Figures 8 and 9 illustrate habit, inflorescence, floral color and size variation of this species. Figure 8 was based on a cultivated specimen from the state of Rio de Janeiro (A. Toscano de Brito 3470, UPCB) and Figure 9 illustrates two cultivated specimens from the state of Paraná (A. Toscano de Brito 3552 and A. Toscano de Brito 3553, UPCB).

Additional material eXAmined: Brazil. Minas Gerais: Itamonte, Parque Nacional do Itatiaia, 1820 m, 25 Jan. 2009, F. Barbarena 131(RB). Paraná: Piraquara, collected by M. Klingelfus s.n., fl. cult. 11 July 2016, A. Toscano de Brito 3553 (UPCB); Rio Branco do Sul, Serra do Bromado, 9 Feb. 1982, G. Hatschbach 44555 (MBM); São José dos Pinhais, Vossoroca, collected by M. Klingelfus s.n., fl. cult. 11 July 2016, A. Toscano de Brito 3552 (UPCB). Rio de Janeiro: Petrópolis, Estrada do Imperador, colleceted by M. Scalia Baltar s.n., fl. cult. 18 Nov. 2015, A. Toscano de Brito 3470 (UPCB); Near Petrópolis, alt. ca. 1000 m, cultivated at Orquidário Binot by Jorge and Maurício Verboonen, 30 November 1989, C. Luer 14519 (SEL). São Paulo: Bananal, Sertão do Rio Vermelho, Serra da Bocaina, 20 May 1936, A.C. Brade 15259 (RB); Campos do Jordão, September 1937, P. Campos Porto s.n. (RB); Campos de Jordão, Itapeva, 1800 m, Feb. 1947, G. Pabst 370 (AMES); Campos de Jordão, Itapeva, March 1947, G. Pabst 370 (AMES, HB); Corrego Alegre, 2 Jan. 1897, A. Loefgren ex Comissão Geográfica e Geológica de São Paulo 3590 (AMES, SP).

Pabstiella elegantula (Cogn.) Luer, Monogr. Syst. Bot. Missouri Bot. Gard. 112: 119. 2007. Fig. 10-11.

Basionym: Pleurothallis elegantula Cogn., Bull. Soc. Roy. Bot. Belgique 43: 308. 1906 (published 1907), not Cogn. 1909. TYPE: Brazil. Rio de Janeiro: without locality: A. Glaziou s.n. (holotype: BR [658530]).

Synonyms: Pleurothallis avenacea Ames, Orchidaceae 2: 266. 1908, syn. nov. TYPE: without locality: flowered in cultivation 18 May 1907, O. Ames s.n. (lectotype here designated: AMES [7389 collection "III"]). SYNTYPES: without locality: flowered in cultivation, 2 March 1904, O. Ames s.n. (AMES [6098 - collection "I"]); flowered in cultivation, 14 January1903, O. Ames s.n. (AMES [6098 - collection "II"]); flowered in cultivation 28 February 1905, O. Ames s.n. (AMES [7389 collection "I"]); flowered in cultivation 28 March 1906, O. Ames s.n. (AMES [7389 - collection "II"]).

Pleurothallis leucosepala Loefgr., Arch. Jard. Bot. Rio de Janeiro 2: 49. 1918, syn. nov. TYPE: Brazil. São Paulo: Guaratinguetá, 1917, P. Campos Porto s.n. (holotype: RB [8251]).

Pleurothallis mathildae Brade, Orquídea (Rio de Janeiro) 6: 12 (1943), syn. nov. TYPE: Brazil. Rio de Janeiro: Nova Friburgo, 23 November 1940, M.S. Odebrecht s.n. (holotype: RB [46413]).

Trichosalpinx mathildae (Brade) Toscano \& Luer, Kew Bull. 48: 326 (1993), syn. nov.

Specklinia avenacea (Ames) Luer, Monogr. Syst. Bot. Missouri Bot. Gard. 95: 259. 2004, syn. nov. Specklinia elegantula (Cogn.) Luer, Monogr. Syst. Bot. Missouri Bot. Gard. 95: 260. 2004, syn. nov. Specklinia leucosepala (Loefgr.) Luer, Monogr. Syst. Bot. Missouri Bot. Gard. 95: 261. 2004, syn. nov.

Pabstiella avenacea (Ames) Luer, Monogr. Syst. Bot. Missouri Bot. Gard. 112: 119. 2007, syn. nov. Pabstiella leucosepala (Cogn.) F. Barros \& C.F. Hall, Orquidário 26(1): 29. 2012, syn. nov.

Study of the type specimens of Pleurothallis avenacea Ames, Pleurothallis elegantula Cogn, and Pleurothallis mathildae Brade has shown that these taxa are all conspecific. Differences in floral size, sepal carination, and sheaths of the ramicauls are simply extremes within a spectrum.

Pabstiella elegantula (Cogn.) Luer was first described in the genus Pleurothallis R.Br. It is a frequent species in the Atlantic forests of Rio de Janeiro and São Paulo, in southeast Brazil. Although uniform in the shape of floral segments, the flower size is otherwise very variable and this might have contributed to the list of synonymies presented here. For example, sepal length ranging from 5 to $9 \mathrm{~mm}$ long may be found throughout a continuum. The type specimen of Pleurothallis elegantula, with sepals about $5 \mathrm{~mm}$ long, represents a small flowered extreme, $P$. mathildae, with sepals about $7 \mathrm{~mm}$ long, and $P$. leucosepala, with $8 \mathrm{~mm}$ long sepals, represent 


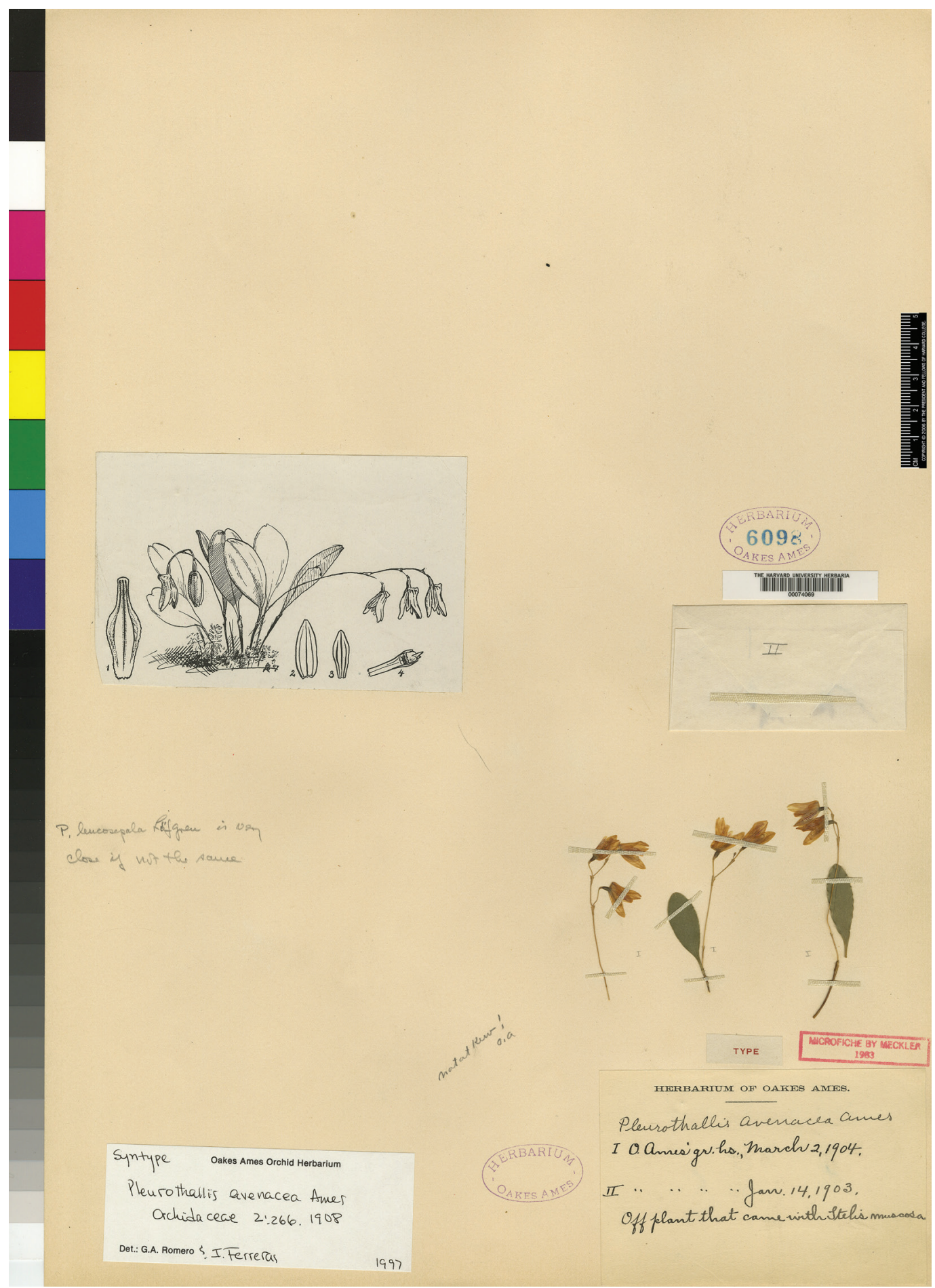

FiguRe 10. Pabstiella elegantula. Syntypes of Pleurothallis avenacea deposited at AMES. Herbarium sheet nr. 6098 contains two collections: number "I", dated 2 March 1904, and number "II", dated 14 January 1903. Courtesy of the Orchid Herbarium of Oakes Ames, Harvard University Herbaria. 


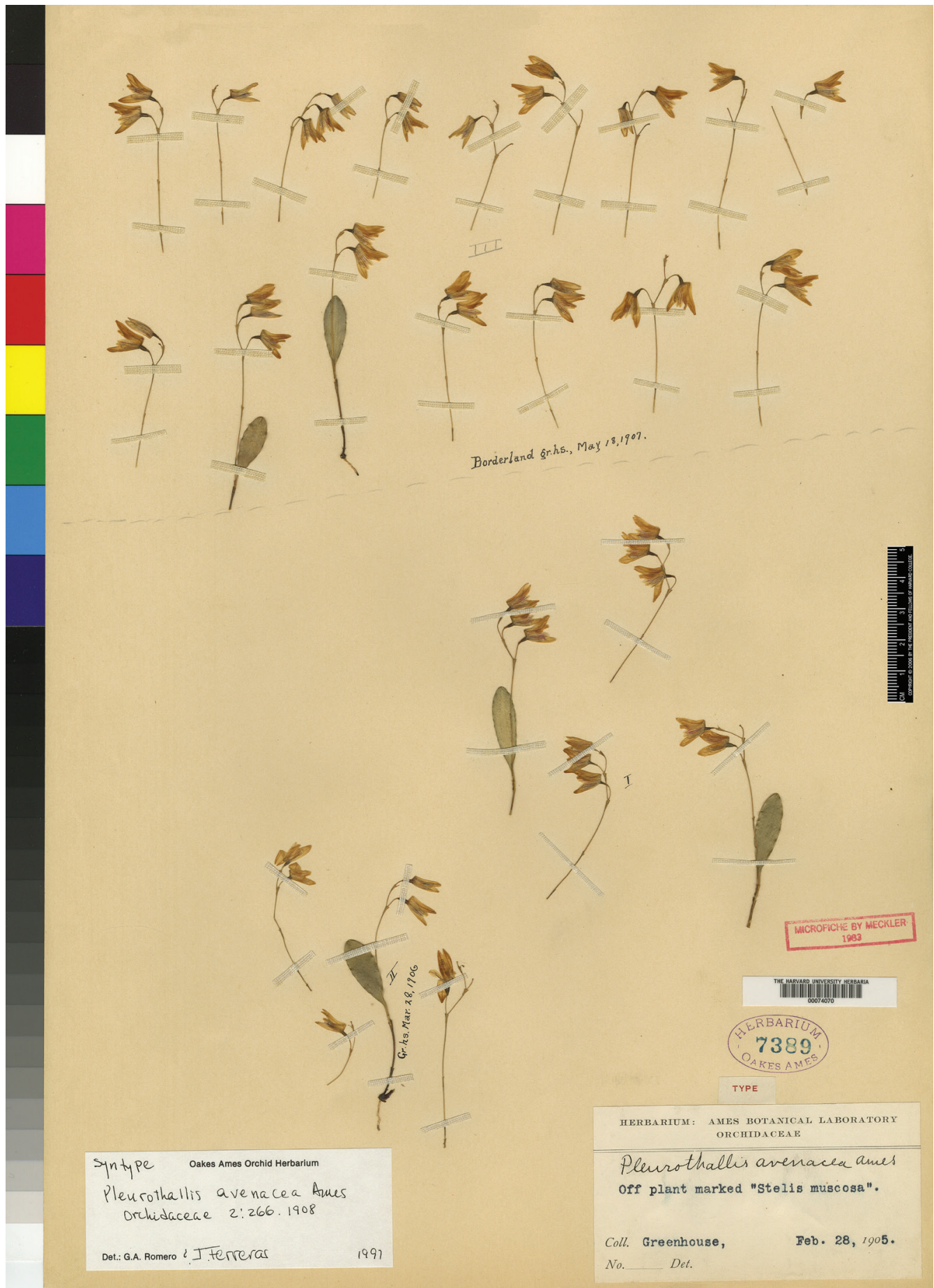

FIGURE 11. Pabstiella elegantula. Syntypes of Pleurothallis avenacea deposited at AMES. Herbarium sheet 7389 contains three distinct collections: collection "I", dated 28 February 1905; collection "II", dated 28 March 1906, and collection "III", dated 18 May 1907. Collection "III" has been here designated as lectotype of Pleurothallis avenacea. Courtesy of the Orchid Herbarium of Oakes Ames, Harvard University Herbaria. 
intermediate forms, while the type specimens of $P$. avenacea, with about $9 \mathrm{~mm}$ long sepals, are just large flowered extremes. The sheaths of the ramicauls are also variable. Some specimens possess typical pseudolepanthiform sheaths (as described by Toscano de Brito \& Luer, 2013) but in others the sheaths are apparently glabrous with only obscurely thickened ostia.

Oakes Ames described Pleurothallis avenacea based on a collection of unknown origin, according to him "introduced to horticulture from Tropical America" (Ames 1908). He cited in the protologue two collection numbers from his herbarium, 6098 and 7389 , without selecting one of them as the holotype. These herbarium specimens are preserved at AMES. Each herbarium sheet contains inflorescences and fertile ramicauls from distinct collections made from cultivated plants which flowered at different times. The herbarium sheet 6098 (Fig. 10) contains two collections numbered in Roman numerals: number "I", dated 2 March 1904, and number "II", dated 14 January 1903. The herbarium sheet 7389 (Fig. 11) contains three distinct collections; these are also numbered in Roman numerals: collection "I" is dated 28 February 1905, collection "II" is dated 28 March 1906, and collection "III" is dated 18 May 1907. With exception of collection number "III" on herbarium sheet nr. 7389, all other specimens seem to have been collected from Ames's orchid nursery located at his home in Boston. Collection number "III" on herbarium sheet nr. 7389 came from his orchid nursery located in the family's country state that the Ameses named as Borderland, which is located in the towns of Easton and Sharon, in Massachusetts. The country estate remained in the family for 65 years and is now a state Park (http:// www.mass.gov/dcr/parks/borderland/index.htm). The illustration in the protologue of Pleurothallis avenacea was prepared by Ames's wife, Blanche, in 1907. It is then safe to assume that the illustration was based on the Borderland specimens mounted on sheet nr.7389, which flowered on 18 May 1907. This collection is also the most representative, possessing complete fertile specimens and many inflorescences. It is therefore chosen herein as the lectotype of Pleurothallis avenacea.

ADDITIONAL MATERIAL EXAMINED: Brazil. Without locality: obtained from F. Miranda, flowered in cultivation by George Schudel at Middleburg, Florida,
25 June 1996, C. Luer 17933 (SEL). Rio de Janeiro: Near Petrópolis, ca. 1000 m, cultivated at Orquidário Binot by Jorge and Maurício Verboonen, 30 November 1989, C. Luer 14494 (SEL); Organ Mountains, near Teresópolis, 2 December 1946, Hunnewell 18489 A (AMES).

Pabstiella leucopyramis (Rchb.f.) Luer, Monogr. Syst. Bot. Missouri Bot. Gard. 112: 120. 2007. Fig. 12-15.

Basionym: Pleurothallis leucopyramis Rchb.f., Linnaea 41: 47. 1876. TYPE: Without locality: flowered in cultivation at Hamburg Botanical Garden, 1874, W. Saunders 2185 (holotype: W [R53823]; drawings of the holotype: W [R-53821]; Isotype: K [000584222]).

Synonyms: Humboldtia leucopyramis (Rchb.f.) Kuntze, Revis. Gen. P1. 2: 667. 1891.

Pleurothallis pterophora Cogn., Fl. Bras. (Mart.) 3(4): 583. 1896, syn. nov. TYPE: BRAZIL. Rio de Janeiro: Petrópolis, Retiro, Morro da Carangola, 22 December 1882, A. Glaziou 14305 (lectotype here designated: $\mathrm{BR}$ [658598]; isolectotypes: $\mathrm{K}$ [000940360], P [00489476], LE [LE00001425]. Rio de Janeiro: Alto Macaé, A. Glaziou 17267 (Syntype: P [00489477]; isosyntype: K [000940363]).

Pleurothallis pterophora var. minor Cogn., Fl. Bras. (Mart.) 3(4): 584. 1896, syn. nov. TYPE: Brazil. Rio de Janeiro: Alto Macaé, 1892, A. Glaziou s.n. (holotype: BR [658461]).

Trichosalpinx pterophora (Cogn.) Luer, Phytologia 54: 397. 1983, syn. nov.

Specklinia leucopyramis (Rchb.f.) Luer, Monogr. Syst. Bot. Missouri Bot. Gard. 95: 261 (2004), syn. nov.

Pabstiella pterophora (Cogn.) Chiron, Phytotaxa 46: 55. 2012, syn. nov.

Pleurothallis leucopyramis Rchb.f. (= Pabstiella leucopyramis (Rchb.f.) Luer) was described by $\mathrm{H}$. G. Reichenbach from plants obtained from William Wilson Saunders at Reigate, England, which flowered in cultivation at Hamburg Botanical Garden. Nothing was known about its provenance, but during many years it was thought to be Costa Rican in origin (Reichenbach 1878; Veitch 1889). This collection is preserved in Reichenbach herbarium at $\mathrm{W}$ and a duplicate (two inflorescences) is kept at $\mathrm{K}$. Both $\mathrm{K}$ 


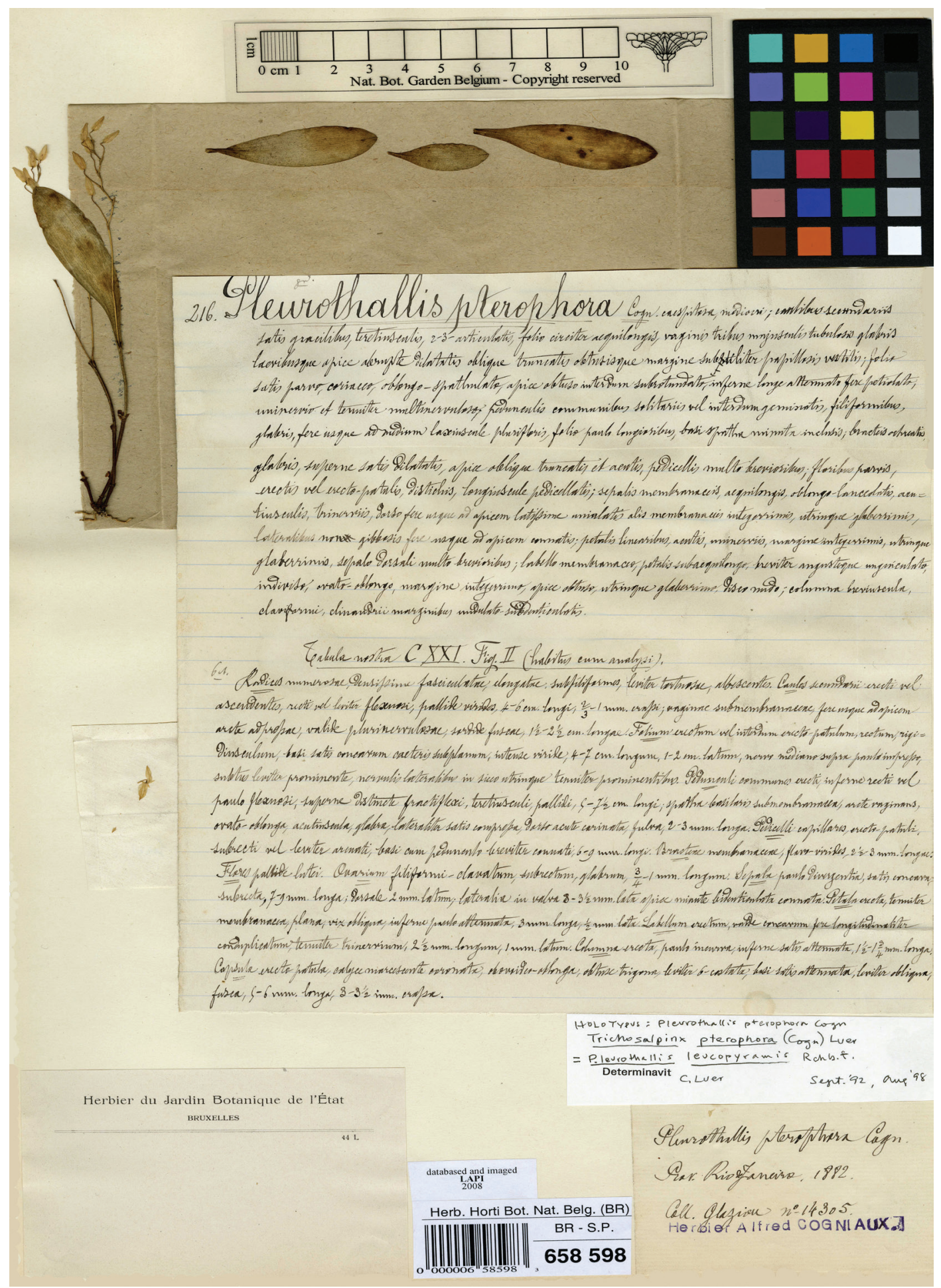

FIGURE 12. Pabstiella leucopyramis. Lectotype of Pleurothallis pterophora, here designated: A. Glaziou 14305 (BR). Reproduced with permission. Copyright: Jardin Botanique Meise. 


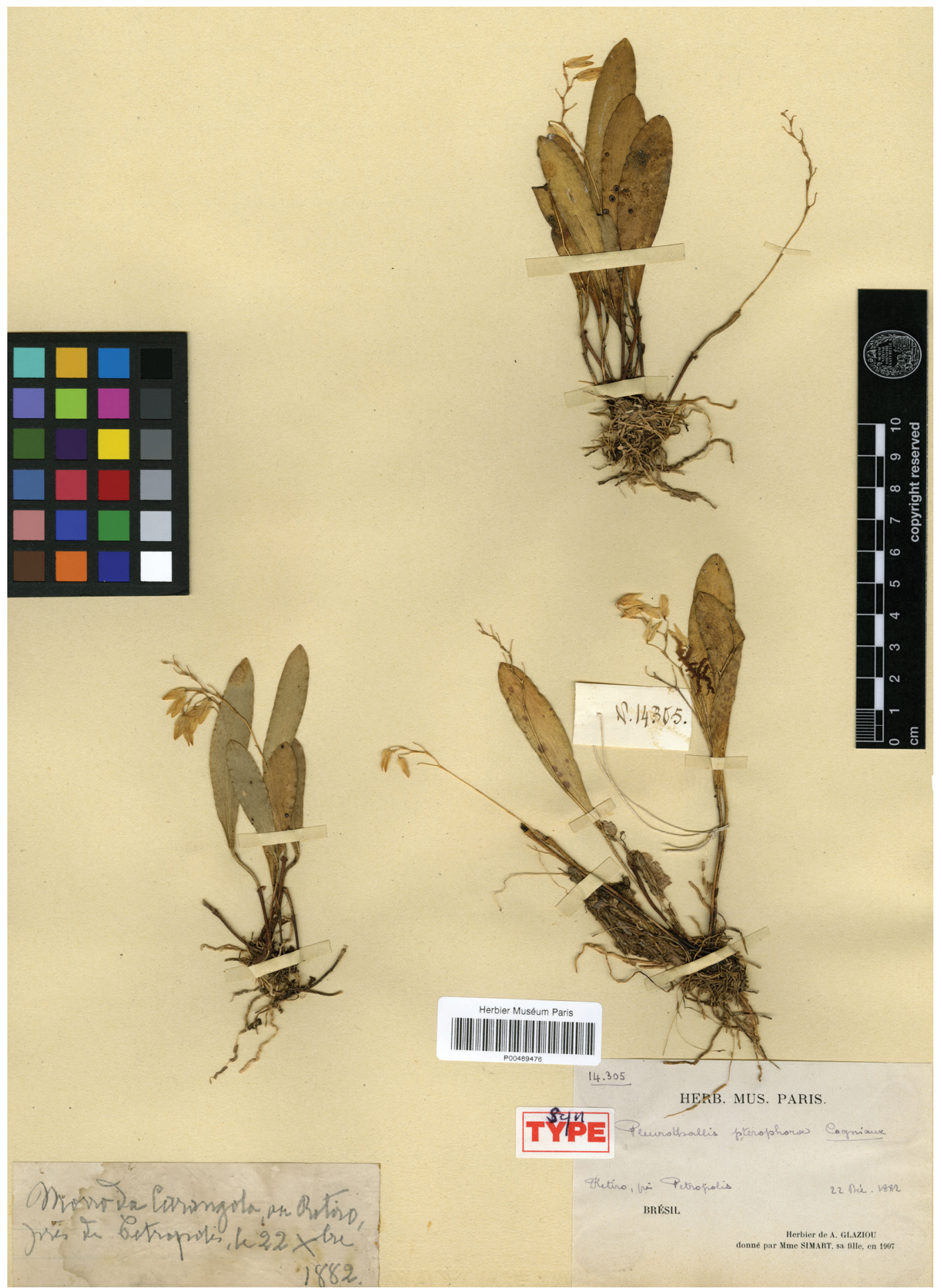

FiguRE 13. Pabstiella leucopyramis. Isolectotype of Pleurothallis pterophora deposited at P containing detailed flowering season and provenance information. Reproduced with permission of the Muséum National d'Histoire Naturelle (Paris). 

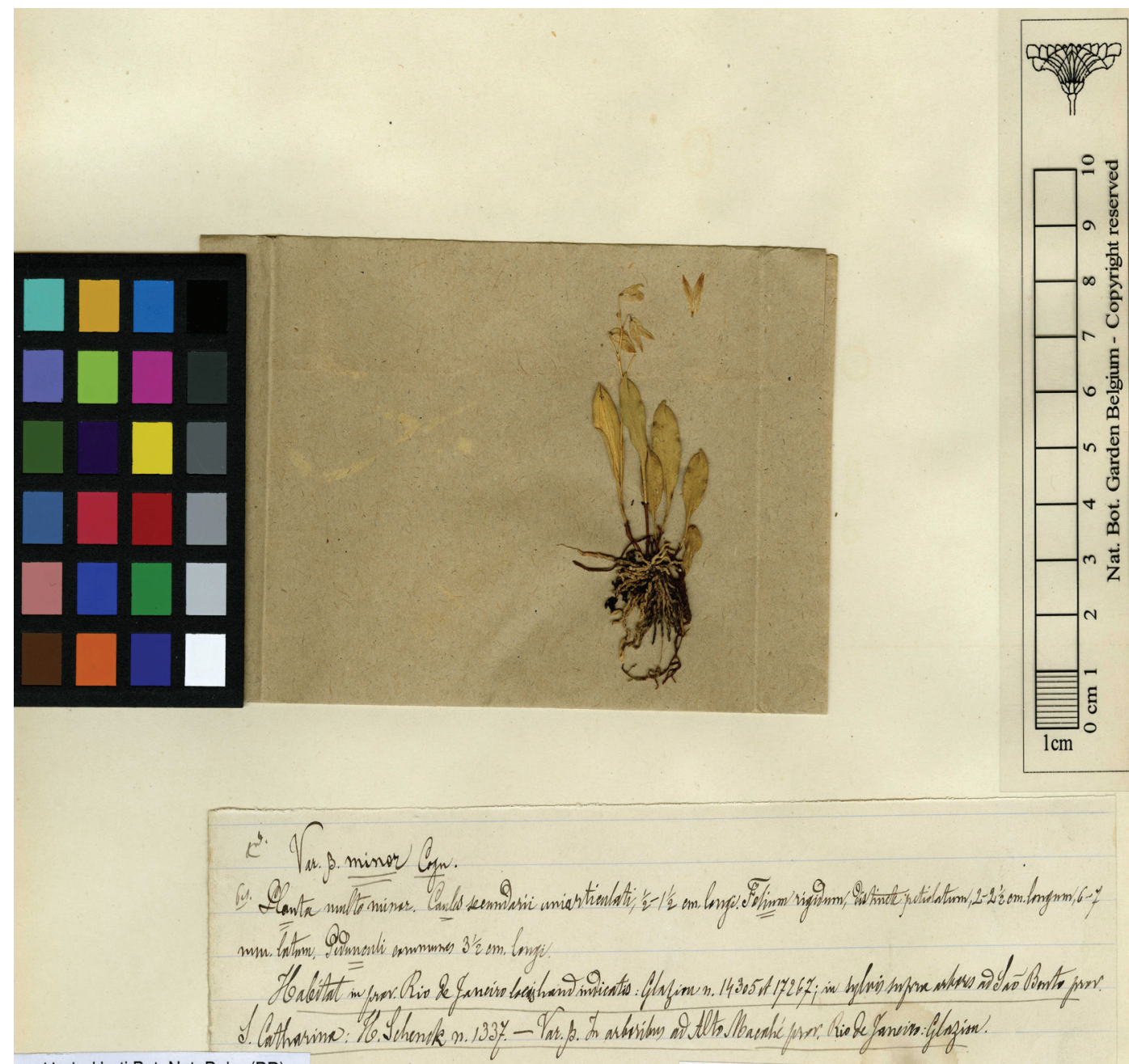

Herb. Horti Bot. Nat. Belg. (BR)
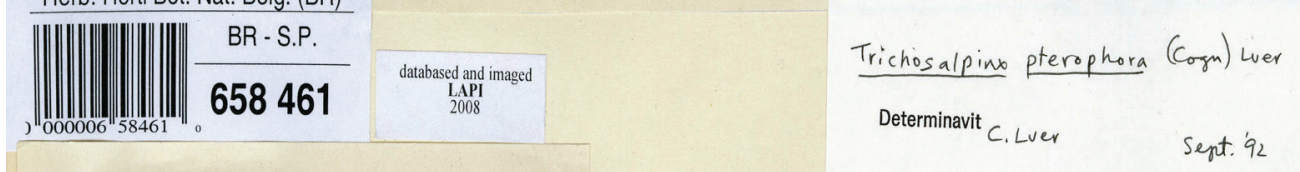

Herbier du dardin Botanique de l’État BRUXELLES

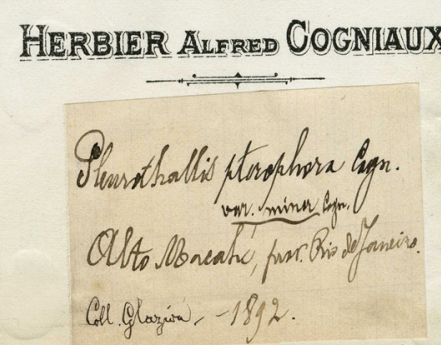

Figure 14. Pabstiella leucopyramis. Holotype of Pleurothallis pterophora var. minor deposited at BR (A. Glaziou s.n.). Reproduced with permission. Copyright: Jardin Botanique Meise. 
$\mathbf{A}$

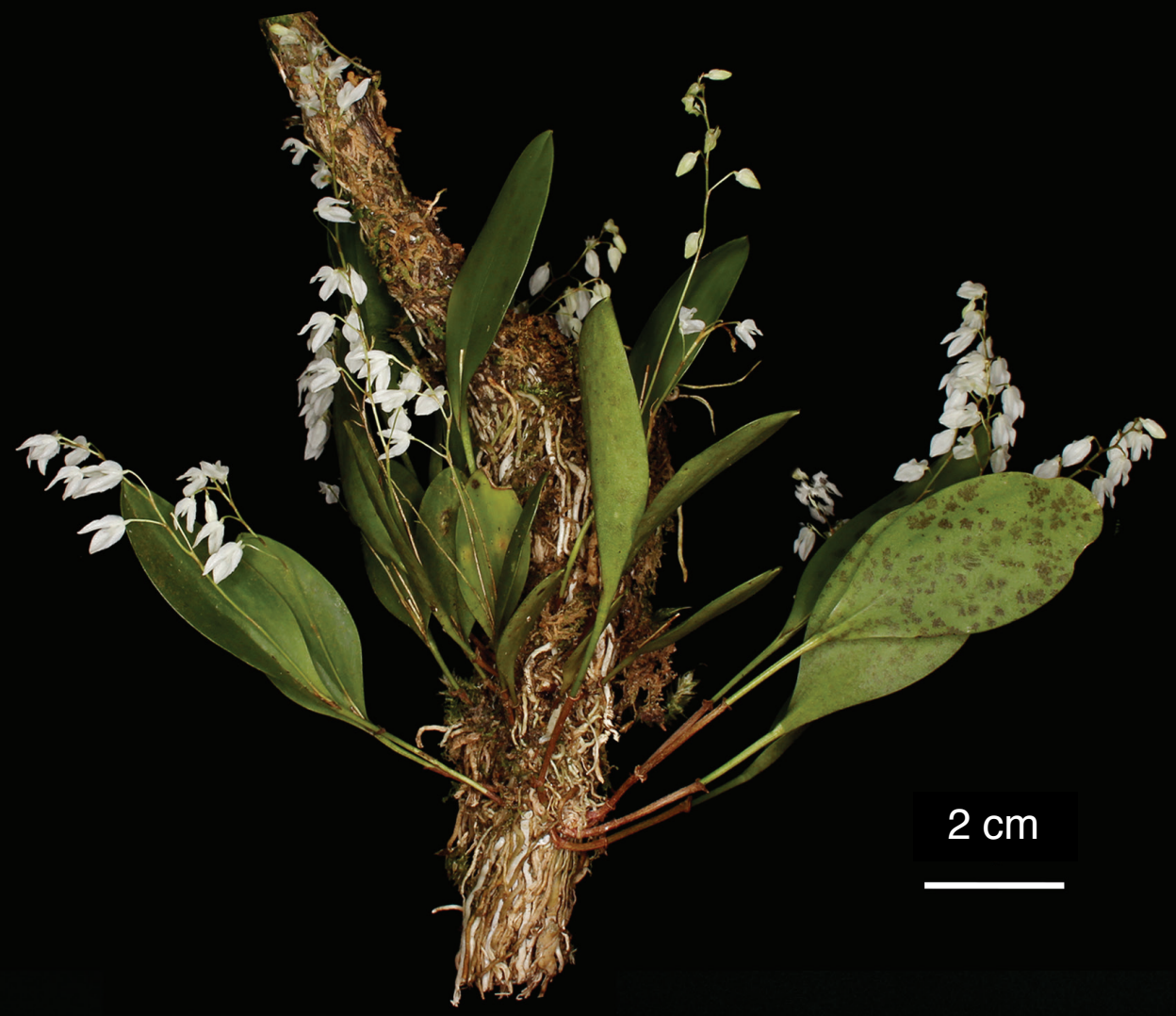

B

C
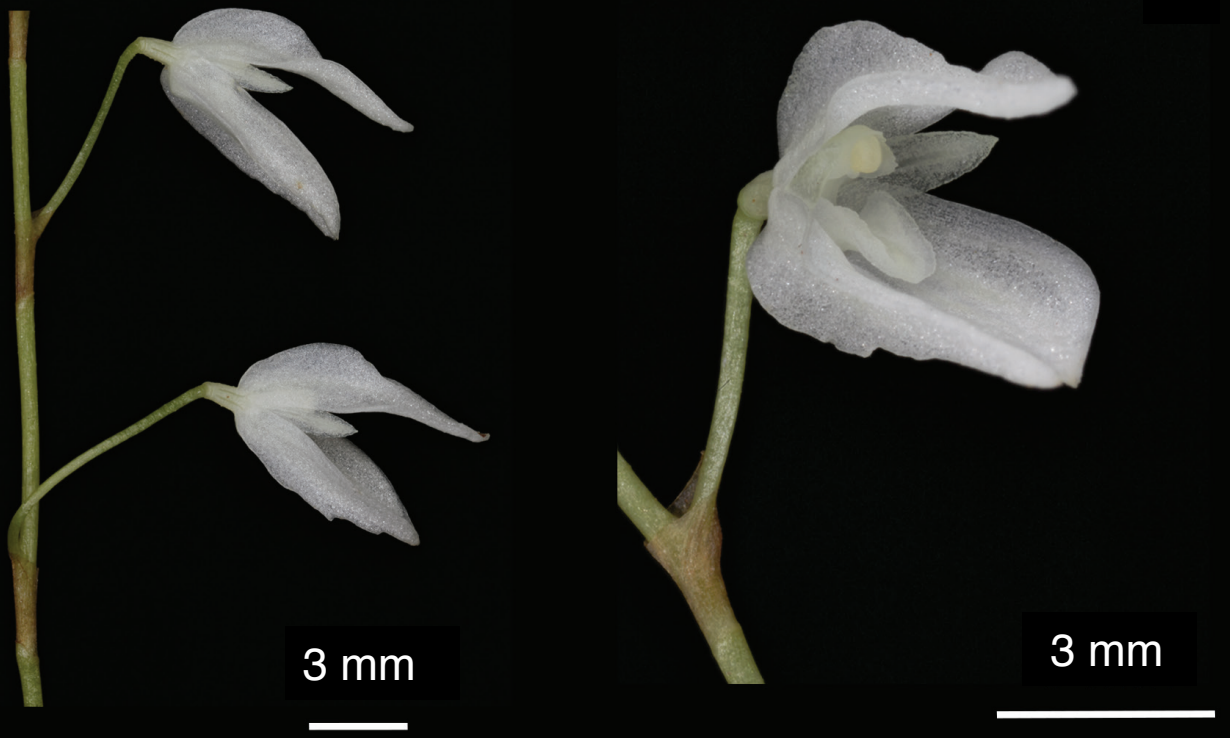

Figure 15. Pabstiella leucopyramis. A - Habit; B - Portion of inflorescence with flowers in side view; C - Flower, 3/4 view. Based on A. Toscano de Brito 3500 (UPCB). Photograph by W. Collier \& A. Toscano de Brito. 
and $\mathrm{W}$ collections were studied by the authors. The collection at W bears Saunders's number 2185, but this number is not cited in the protologue.

Study of the type specimens of Pleurothallis pterophora Cogn., an endemic species in southeast Brazil and recently transferred to Pabstiella by Chiron (2012), has shown that this species and P. leucopyramis are inseparable. They share the same vegetative and floral morphology.

Cogniaux (1896) cited three syntype specimens in the protologue of Pleurothallis pterophora, namely: two Glaziou's collections, 14305 and 17267, from Rio de Janeiro, and a Schenck's collection 1337, from Santa Catarina. We did not locate Glaziou's nr. 17267 at BR or Schenck's nr. 1337. However, duplicates of Glaziou's collections exist at K (14305 and 17267), P (14305 and 17267), BR (14305) and LE (14305). We here select the specimen A. Glaziou 14305 deposited at BR (Fig. 12 ) as the lectotype of Pleurothallis pterophora Cogn. Many of Glaziou's collections are known to usually lack precise localities. However, study of a duplicate of this collection deposited at P (Fig. 13) provides detailed flowering season and provenance information of the lectotype of Pleurothallis pterophora. The collection was made in December 1882 and comes from Morro da Carangola, in Retiro, today a district of the city of Petrópolis, in the state of Rio de Janeiro. The holotype of Pleurothallis pterophora var. minor Cogn. (Fig. 14) was also examined and proved to be just a small individual of Pabstiella leucopyramis. Figure 15 illustrates a collection from Venda Nova do Imigrante, state of Espírito Santo, in southeast Brazil.

Pabstiella pristeoglossa (Rchb.f. \& Warm.) Luer, Monogr. Syst. Bot. Missouri Bot. Gard. 112: 120. 2007. Fig. 16-19.

Basionym: Pleurothallis pristeoglossa Rchb.f. \& Warm., Otia Bot. Hamburg. 2(1): 92. 1881. TYPE: Brazil. Minas Gerais: Lagoa Santa, E. Warming 75 - number not cited in the protologue - (holotype: C [Lost]; lectotype here designated: Reichenbach's original drawings of a flower from the holotype, prepared in December 1880, and deposited at W [R53811]; epitype here selected: Warming's original drawing nr. 75, partially reproduced in Warming, Symbolae 29: 358, tab. 4. fig. 3. 1883[publ. in 1884], and now deposited at C).
Synonyms: Humboldtia pristeoglossa (Rchb.f. \& Warm.) Kuntze, Revis. Gen. P1. 2: 668. 1891.

Specklinia pristeoglossa (Rchb.f. \& Warm.) Luer, Monogr. Syst. Bot. Missouri Bot. Gard. 95: 263. 2004.

Pabstiella cipoensis L.Kollmann, Candollea 65: 98. 2010. TYPE: Brazil. Minas Gerais: Serra do Cipó, 15 July 1998, fl. in cult. 30 August 2007, L. Kollmann \& R.L. Kolmann 10000 (holotype: MBML [39764]; isotype: RB [498577]), syn.nov.

Pleurothallis pristeoglossa Rchb.f. \& Warm. [= Pabstiella pristeoglossa (Rchb.f. \& Warm.) Luer] was discovered by Eugen Warming (1841-1924) during his expeditions to Lagoa Santa in the Brazilian state of Minas Gerais, between 1863 and 1866. Warming prepared detailed illustrations of the orchids he collected and these, together with spirit specimens and notes, were sent to Reichenbach for identification. Over 60 species were found to be new (Warming 1884) and were published by Reichenbach (1881) in Otia Botanica Hamburgensia. Warming co-authored all new species he collected, except those named after him. Warming's original drawings and collections are preserved at C. In Reichenbach orchid herbarium at W, the only herbarium sheet attributed to this species is numbered 53811 and it has been marked as "typus" by the staff at W (Fig. 16). It contains two illustrations: An incomplete, tracing copy of Warming's drawings (Fig. 16A), whose originals are preserved at $\mathrm{C}$, and a sketch prepared by Reichenbach, in December 1880, based on a spirit preserved flower from a specimen collected by Warming 75 (Fig. 16B). The drawing on the right side of the sheet (Fig. 16B) bears the following note in Reichenbach's handwriting: "Rchb.f. ad sp. Warming alc" (= Rchb.f. ad specimen Warmingiani alcoholi). This means that Reichenbach made the drawing based on a Warming's specimen preserved in alcohol. He did not explicitly cite a collection in the protologue, but this was the standard practice of the time. He only cited Warming's illustration at that time still unpublished. It is not clear whether Warming's spirit collection comprised a complete specimen or only flowers. The description provided in the protologue of Pleurothallis pristeoglossa is fairly detailed, including information on vegetative and inflorescence parts, something that Reichenbach could not have done studying flowers alone. Warming's spirit collection was not located by the staff at C (H. Pedersen 2013, pers. 


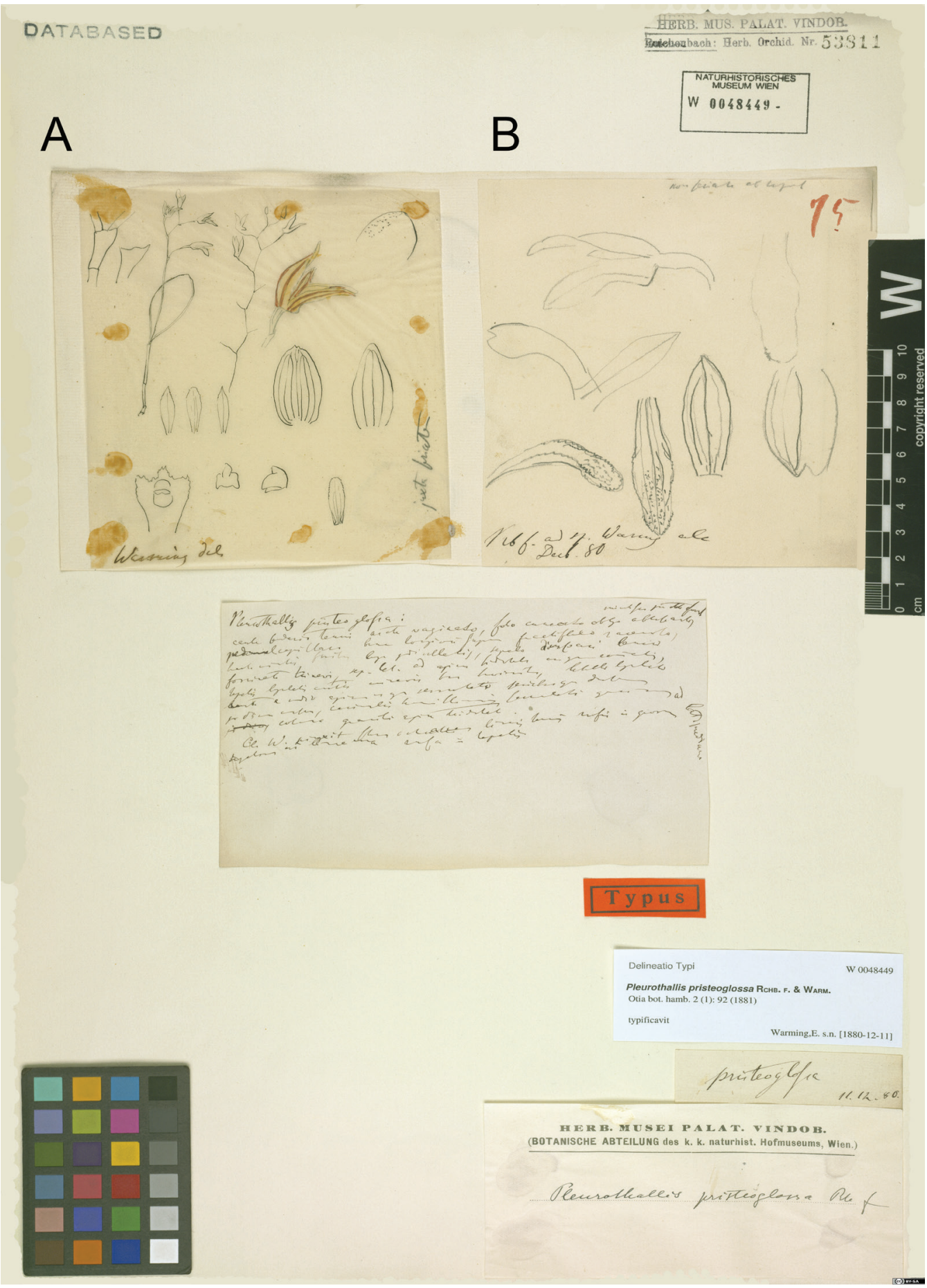

FiguRE 16. Pabstiella pristeoglossa. Herbarium sheet at W containing two illustrations of Pleurothallis pristeoglossa: A Incomplete, tracing copy of Warming's drawings whose originals are preserved at C, and B - Reichenbach's original drawings based on a flower from the lost holotype specimen (Warming 75), lectotype here designated. Reproduced with permission of the Natural History Museum Vienna. 


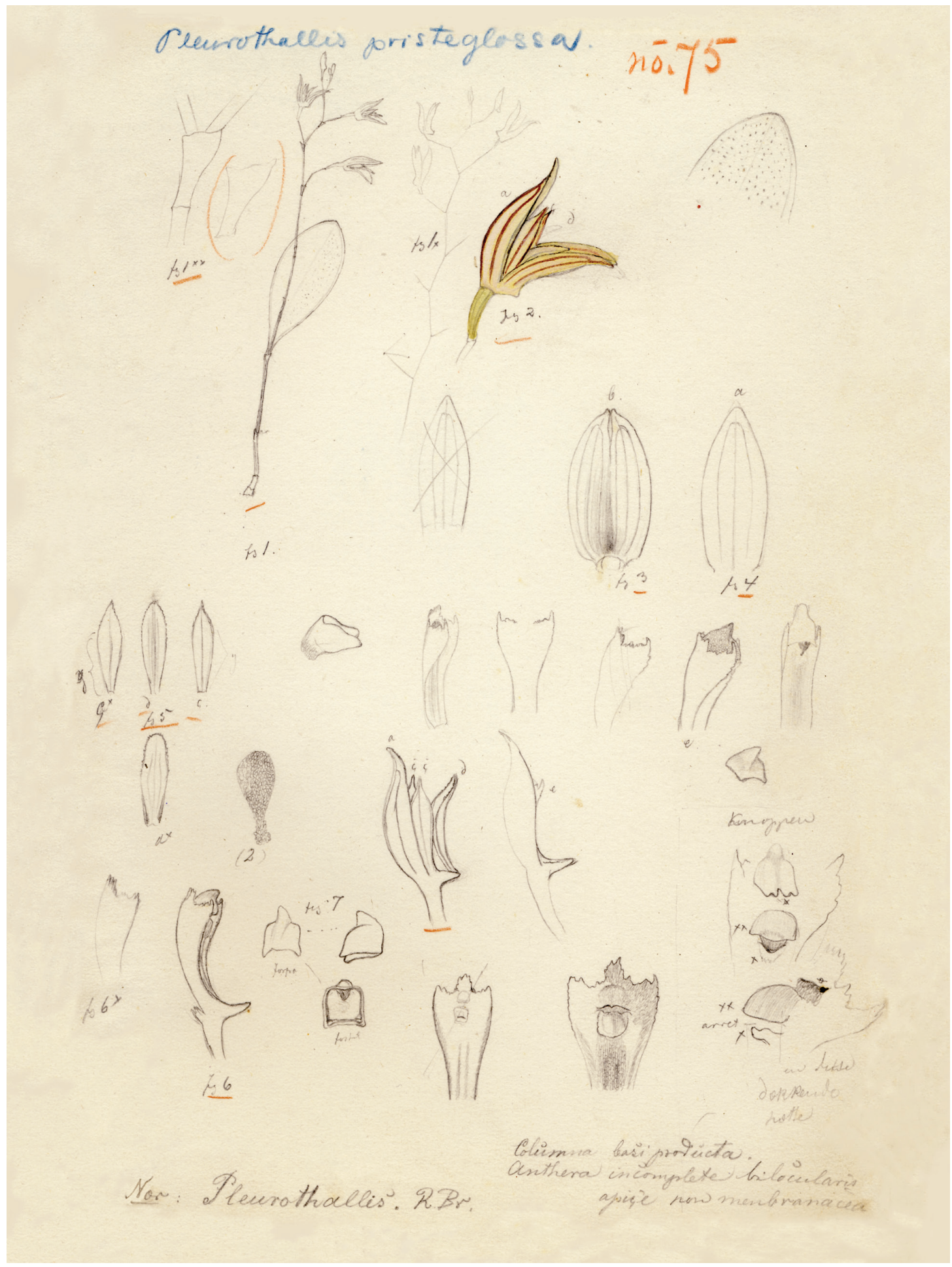

FIgURE 17. Pabstiella pristeoglossa. Warming's original illustration nr. 75 deposited at C and here designated as epitype of Pleurothallis pristeoglossa. Reproduced with permission of the Natural History Museum of Denmark. 

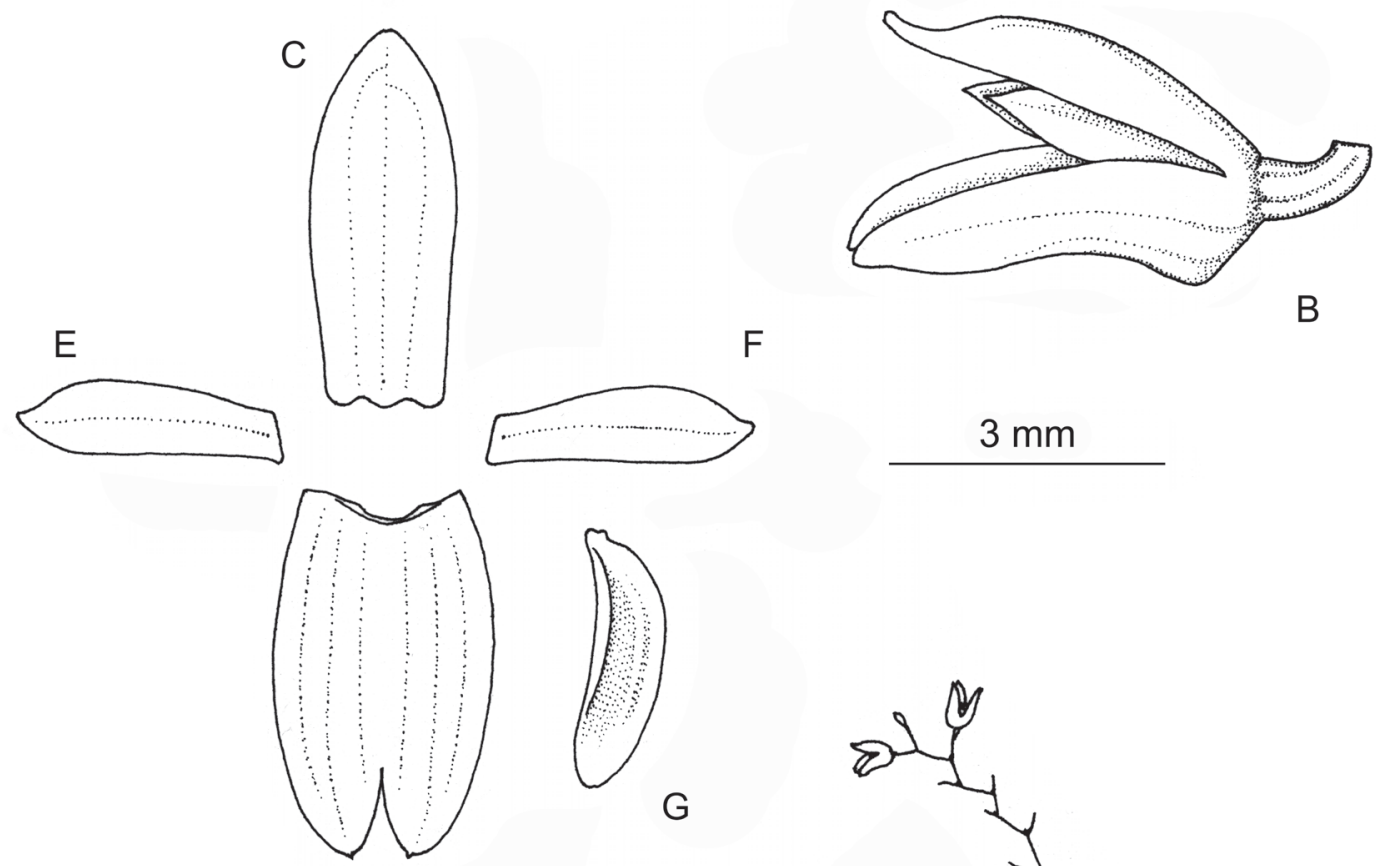

B
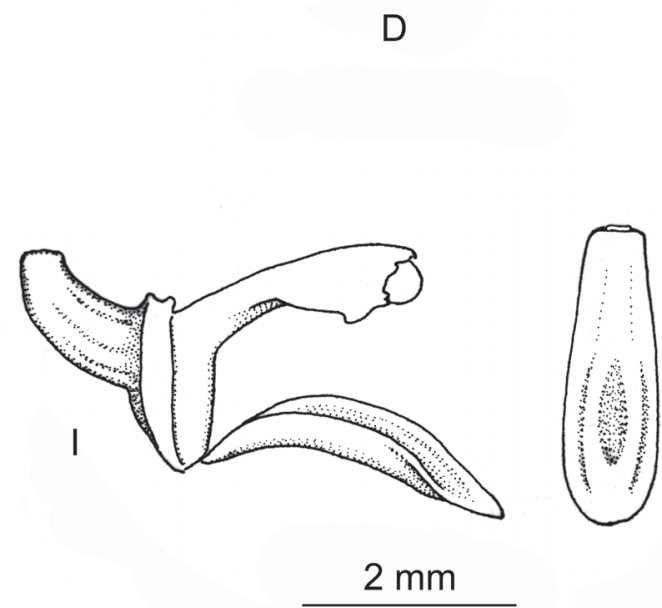

$\mathrm{H}$

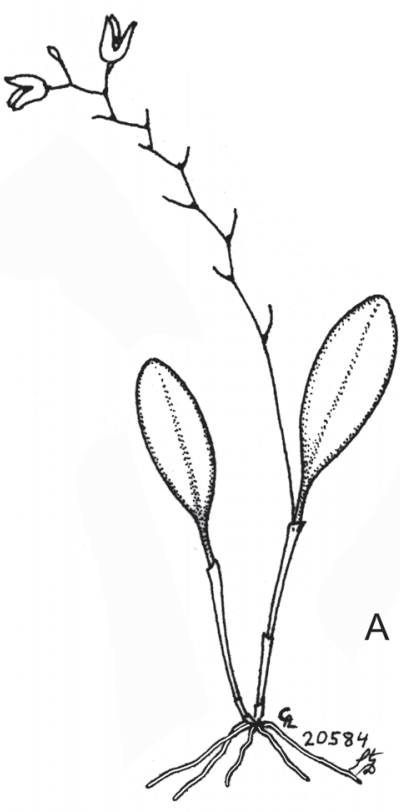

$5 \mathrm{~cm}$

Figure 18. Pabstiella pristeoglossa. A - Habit; B - Flower, side view; C - Dorsal sepal; D - Synsepal; E-F - Petals; G-H -

Lip; I - Ovary, column and lip, side view. Drawn by C. A. Luer based on M. Borges s.n. (MBML).

comm.) and might have been lost or destroyed. It is here assumed that this collection contained a complete, fertile specimen. However, it is also possible that Warming's spirit collection comprised only flowers (or flower) and Reichenbach's description was actually based on these flowers and on Warming's detailed, original illustration. The unpublished drawing prepared by Reichenbach, which is located on the right side of the herbarium sheet and shows a floral dissection of Warming's specimen, is here selected as the lectotype among the extant original materials. Warming's original illustration number 75 (Fig. 17) deposited at $\mathrm{C}$ is additional, original material that complements Reichenbach's drawings. It depicts a complete specimen as well as detailed floral analyses. It provides important, morphological features for recognition of the species and is therefore here selected 


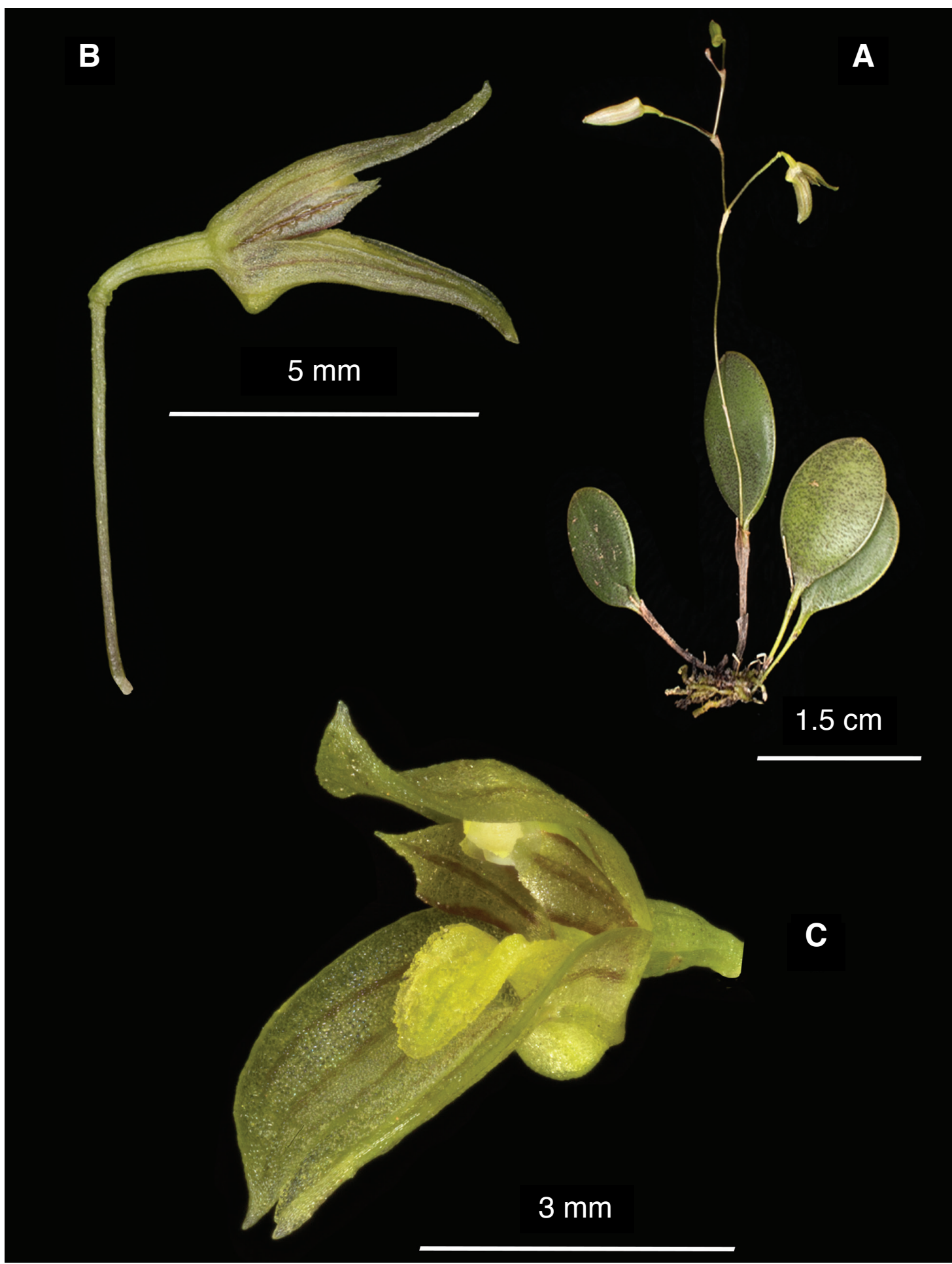

Figure 19. Pleurothallis pristeoglossa. A - Habit; B - Flower, side view; C - Flower, 3/4 view. Based on A. Toscano de Brito 3525 A (UPCB). Photograph by W. Collier \& A. Toscano de Brito. 


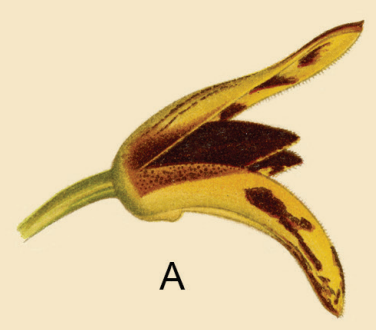

A

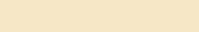

E

$5 \mathrm{~mm}$

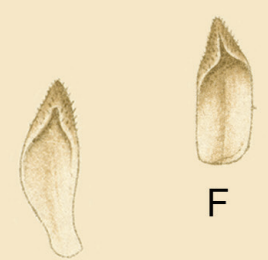

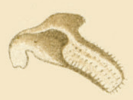

$\mathrm{H}$

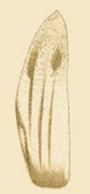

G

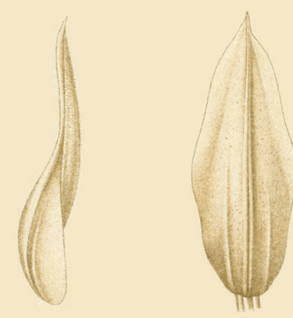

B

C

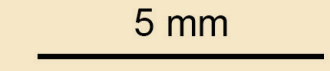

FIgure 20. Pabstiella versicolor. Illustration of Pleurothallis versicolor published by Porsch in 1906, which appeared in Ergebnisse der Botanischen Expedition der Kaiserlichen Akademie der Wissenschaften nach Südbrasilien 1901. Band I: 18, plate 12, figures 16-23. The illustration is here modified to show floral segments with estimate scales. A - Flower, side view; B - Dorsal sepal, side view; C - Dorsal sepal, abaxial view; D - Synsepal, adaxial view; E-F - Petals, variation in shape, adaxial view; G - Petal, abaxial view; H - Lip, 3/4 view.

as the epitype of Pleurothallis pristeoglossa. A portion of this illustration appeared in Symbolae ad Floram Brasiliae centralis cognoscendam (Warming 1884: tab. 4. fig.3). Figures 18 and 19 presented herein were based on cultivated specimens from the state of São Paulo: $M$. Borges s.n. (MBML) and A. Toscano de Brito $3525 A$ (UPCB).

Study of the holotype of Pabstiella cipoensis L.Kollmann, which has recently been described from Minas Gerais, has shown that this species is conspecific with Pabstiella pristeoglossa. Their types present exactly the same vegetative and floral morphology.

Additional material examined: Brazil. Without collection data: flowered in cultivation by the Verboonens at Orquidário Binot, Petrópolis, 2 October1996, C. Luer 18085 (SEL). Rio de Janeiro: Organ Mountains, obtained from Binot in Petrópolis, June 1979, flowered in cultivation at SEL, 18 Jan. 1980, O.I.C. 3313 (SEL). São Paulo: without locality, flowered in cultivation 27 Feb. 2004, M. Borges s.n. (MBML); obtained from Orquidário Colibri in São Lourenço da Serra, São Paulo, and said to have been collected locally, fl. cult. 2 July 2016, A. Toscano de Brito 3525A (UPCB).

Pabstiella versicolor (Porsch) Luer, Monogr. Syst. Bot. Missouri Bot. Gard. 112: 121. 2007. Fig. 20-23.

Basionym: Pleurothallis versicolor Porsch, Oesterr. Bot. Z. 55: 155. 1905. TYPE: Brazil. São Paulo: Santos, Alto da Serra, 1901, R. Wettstein \& V. F. Schieffner s.n. (WU [0071622, photo seen]).

Synonyms: Pleurothallis podoglossa Hoehne, Arq. Bot. Estado São Paulo, n.s., f.m., 1(1): 12. 1938, syn. nov. TYPE: Brazil. São Paulo: São Paulo, forest of Jardim Botânico de São Paulo, August 1936, O. Handro s.n. (holotype: SP [38565]).

Trichosalpinx podoglossa (Hoehne) Luer, Phytologia 54: 396. 1983, syn. nov.

Specklinia podoglossa (Hoehne) Luer, Monogr. Syst. Bot. Missouri Bot. Gard. 95: 263. 2004, syn. nov. Pabstiella podoglossa (Hoehne) Luer, Monogr. Syst. Bot. Missouri Bot. Gard. 112: 120. 2007, syn. nov. 


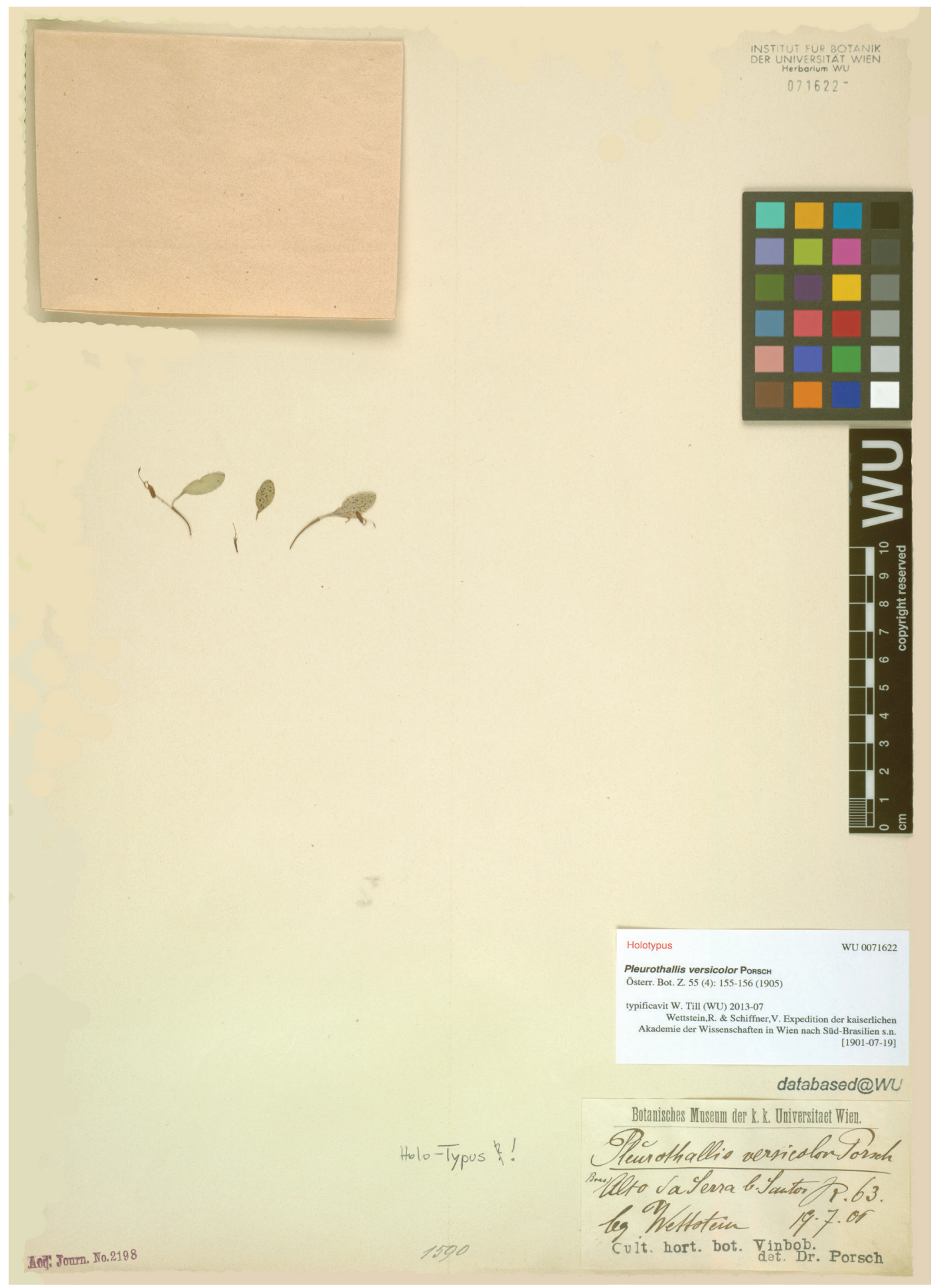

FIGURE 21. Pabstiella versicolor. Holotype specimen of Pleurothallis versicolor deposited at WU. By permission of the Curator, Herbarium of the Institute of Botany, University of Vienna. 

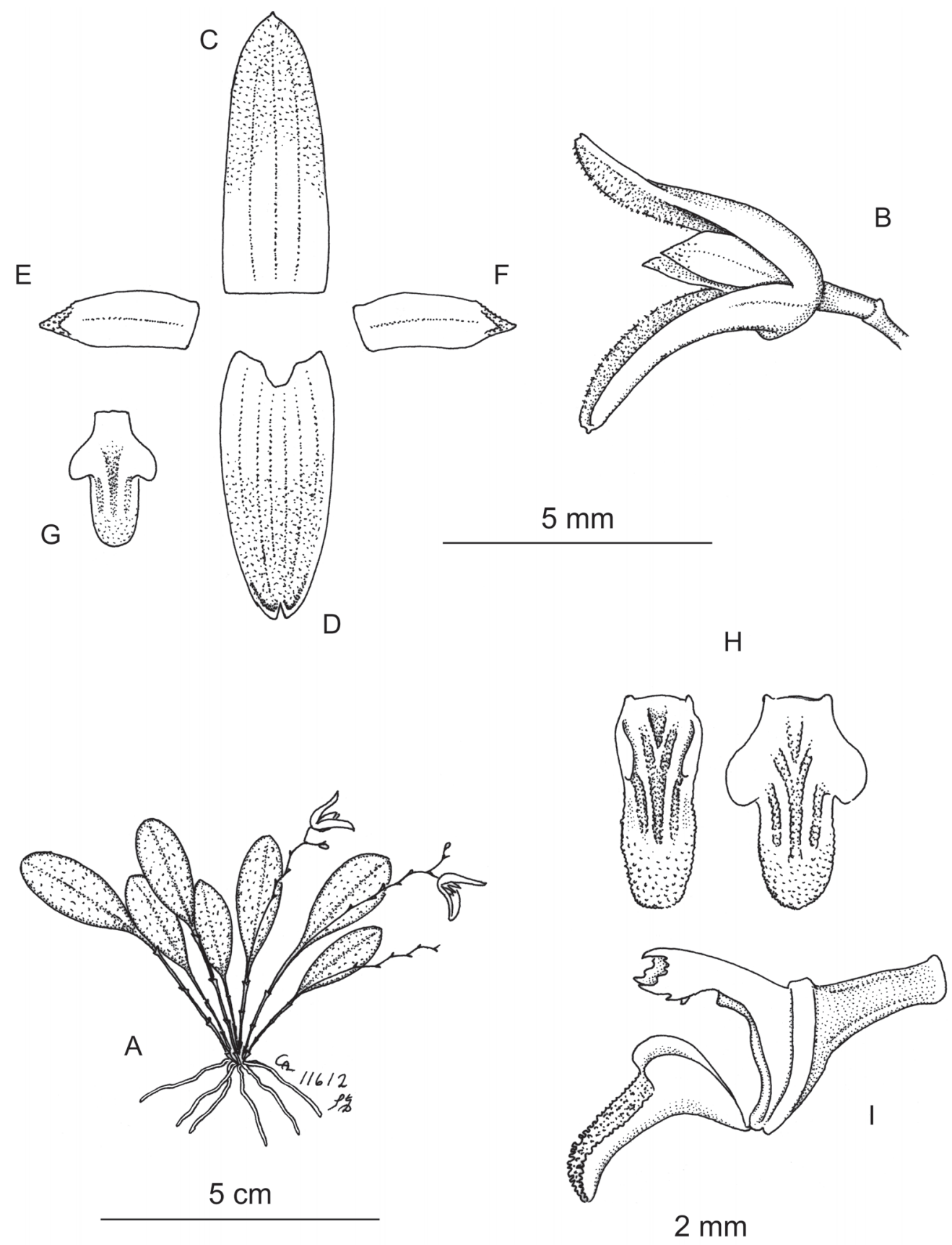

Figure 22. Pabstiella versicolor. A - Habit; B - Flower, side view; C - Dorsal sepal; D - Synsepal; E-F - Petals; G-H - Lip; I - Ovary, column (anther removed) and lip, side view. Drawn by C. A. Luer based on C. Luer 11612 (SEL).

Pleurothallis versicolor Porsch $[=$ Pabstiella versicolor (Porsch) Luer] was described based on a collection by R. Wettstein \& V. F. Schieffner made during the botanical expedition of the Royal
Academy of Science of Vienna to southern Brazil in 1901. The specimen was collected in the municipality of Santos in the state of São Paulo. An illustration was not provided in the protologue, but Porsch (1906) 


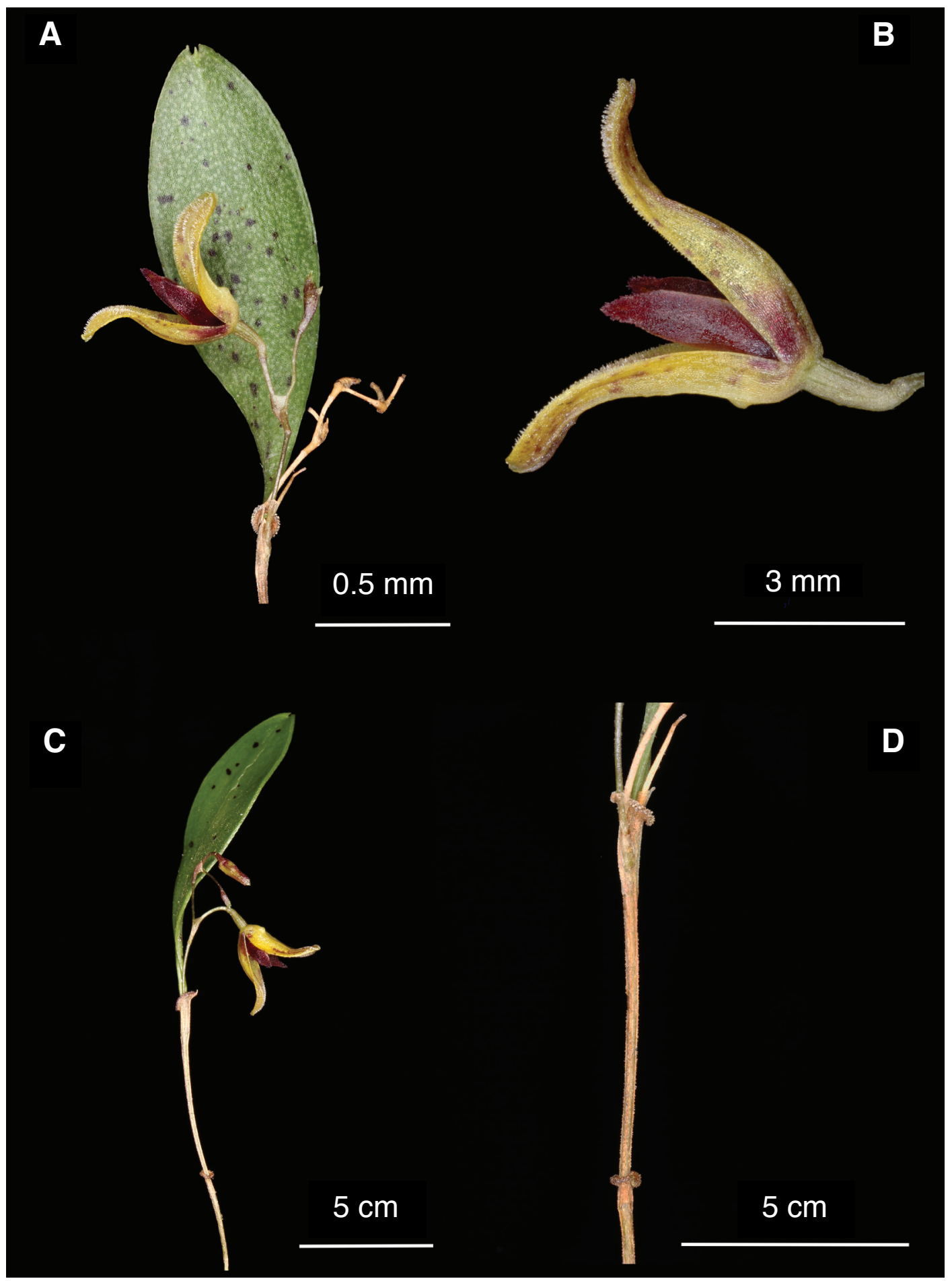

FIgURE 23. Pabstiella versicolor. A - Apical portion of ramicaul, leaf and inflorescence; B - Flower, side view; C - Ramicaul, leaf and inflorescence; D - Pseudo-lepanthiform sheaths of ramicaul. Based on A. Toscano de Brito 3280 (UPCB). Photograph by W. Collier \& A. Toscano de Brito. 
later published a number of fine colored drawings of a flower and floral dissections (Fig. 20). These drawings and the type specimen at WU (Fig. 21) leave no doubt that this species and Pleurothallis podoglossa Hoehne are conspecific. They share the same floral and vegetative morphology, including the same pseudo-lepanthiform sheaths of the ramicauls. Figure 22 shows an illustration based on a specimen cultivated at São Paulo Botanical Garden (C. Luer 11612, SEL), and Figure 23 illustrates a collection from Paraná, south of Brazil (A. Toscano de Brito 3280, UPCB).

Additional material examined: Brazil. Paraná. São José dos Pinhais, Represa do Vossoroca, collected and cultivated by M. Klingelfus s.n., flowered in cultivation 26 July 2014, A. Toscano de Brito 3280 (UPCB). Rio Grande do Sul: Cambuí, Itaimbezinho, collected by L.P. Queiroz s.n., 28 January 1983, flowered in cultivation at São Paulo Botanical Garden, nr. 13338, May 1986, C. Luer 11612 (SEL); Canela, flowered in cultivation, May-April 2012, J. Kelin 69 (UPCB). São Paulo: collected and cultivated near Moji das Cruzes by M. Kayasima s.n., 600 m, 10 March 2007, D.H. Baptista s.n. (SEL). Without collection data: flowered in cultivation by Rafael Bianchi Galanti, Embu, 11 March 2007, D.H. Baptista s.n. (SEL); flowered in cultivation at Orquidário Alvin Seidel, without date, A. Seidel 1309 (SEL).

\section{New Combination}

Pabstiella deltoglossa (Cogn.) Toscano \& Luer, comb. nov. Fig. 24.

Basionym: Pleurothallis deltoglossa Cogn., Bull. Soc. Roy. Bot. Belgique 43: 315.1906 (publ. 1907).

Synomym: Specklinia deltoglossa (Cogn.) Luer, Monogr. Syst. Bot. Missouri Bot. Gard. 95: 260. 2004.

Pleurothallis deltoglossa Cogn. was described based on a specimen collected by Comissão Geográfica e Geológica do Estado de São Paulo nr. 2567. The original Comissão's number 2567 is actually a mixture of two taxa, Pleurothallis acutidentata Cogn. and Pleurothallis deltoglossa, both described as new species by Cogniaux in 1907. We have examined the type specimens of these two species during a recent visit to BR. Images of these specimens can be found in the website of Jardin botanique national de Belgique (http://www.br.fgov.be/RESEARCH/ COLLECTIONS/HERBARIUM/advancedsearch. php). One of them, the holotype of Pleurothallis deltoglossa, is shown in Figure 24 of the present article. In both cases, only one old, badly flattened flower remains in the type sheets of the specimens preserved at BR. While Pleurothallis acutidentata is most probably conspecific with the frequent and rather variable Pleurothallis fusca Lindl. [= Pabstiella fusca (Lindl.) Chiron \& Xim.Bols.], Pleurothallis deltoglossa was shown to be a distinct species presenting a number of features that distinguishes it from other species now placed in the genus Pabstiella. Although similar in habit to several species related to Pabstiella fusca, its floral morphology is quite distinct. As described by Cogniaux (1907), the petals of Pleurothallis deltoglossa are obovate with rounded apex, finely denticulate above, and externally finely papillose, the lip, the most distinctive floral part, is narrowly triangular with entire margins, finely papillose above, and broadly trilobed at apex. The extant, flattened and apparently damaged lip is kept in a small separate envelope on the type sheet. The poor condition of this floral part precluded a proper examination, but it agrees in overall with Cogniaux's description and especially with his sketches, which accompany the type specimen. This species has apparently never been recollected since its discovery and description over a century ago, and can be now extinct. However, it is also possible that it has just been confused in public and private collections with some of the several similarly endemic species to the Atlantic forest of southeast Brazil and may be just waiting to be rediscovered.

ACKNOWLEDGMENTS. The present paper is part of the project "The Pleurothallid Orchids of Brazil: Contributions to an inventory and an understanding of evolution, ecology and conservation," currently sponsored by the Marie Selby Botanical Gardens, and "Estudos filogenéticos e taxonômicos em Pleurothallidinae e Oncidiinae - clado Ornithocephalus (Orchidaceae), sponsored by Universidade Federal do Paraná and Coordenação de Aperfeiçoamento de Pessoal de Nível Superior (CAPES), Brazil. We thank CAPES for grant Programa Pesquisador Visitante Especial (PVE), nr. 88881.065009/2014-0, to ALVTB. We are also 


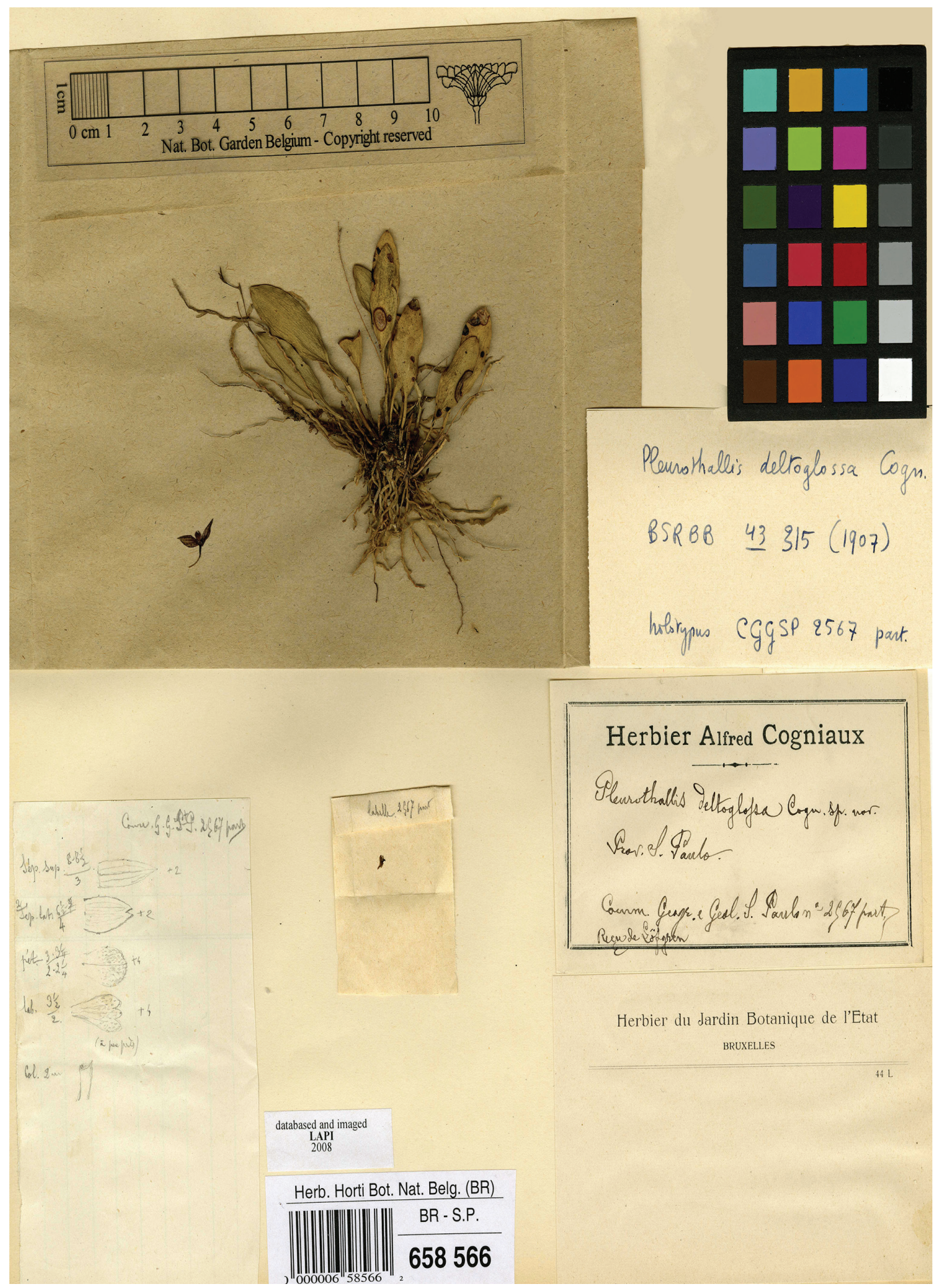

FIgure 24. Pabstiella deltoglossa. Holotype of Pleurothallis deltoglossa at BR. Reproduced with permission. Copyright: Jardin Botanique Meise. 
grateful to the directors and curators of the herbaria cited in this article for sending specimens on loan, allowing access to their collections or making available images of type specimens and historical material. We thank Gustavo A. Romero and Irina Ferrera for their assistance during our visits to AMES and for providing information on Oakes Ames's collections deposited at AMES, Henrik Ærenlund Pedersen for help in obtaining information on Warming's collections deposited at C, and Leslie A. Garay for help in obtaining literature. We acknowledge the services of Coordenação de Proteção e Conservação Florestal, Diretoria de Uso Sustentável da Biodiversidade e Florestas, IBAMA, Brazil, and the Plant Inspection Station at J. F. Kennedy International Airport, New York, U.S.A., for issuing the CITES permits that allowed the exchange and transportation of some specimens treated here; Sistema de Autorização e Informação em Biodiversidade/Instituto Chico Mendes de Conservação da Biodiversidade (SISBIO/ICMBio) for the collecting permits; Jacques Klein, Luiz Filipe Varella, Marcos Klingelfus and Sávio Caliman for providing material for study; Wade Collier and Nancy Karam for help in assembling the illustrations; Stig Dasltröm for inking the line drawings, and the Pleurothallidinae Alliance for making it possible.

\section{LiTERATURE CITED}

Ames, O. (1908). Orchidaceae: Illustrations and studies of the family Orchidaceae, fascicule 2 (pp. 266-267). Boston, Houghton, Mifflin and Company,

Applequist, W. L. (2013). Report of the nomenclature committee for vascular plants 65. In: McNeill, J. (Ed.), Taxon 62(6), 1315-1326. http://dx.doi. org $/ 10.12705 / 626.49$

Barros, F. 2002. Notas nomenclaturas em Pleurothallidinae (Orchidaceae), principalmente brasileiras. Bradea 8, 293-297.

Barros, F., Vinhos, F., Rodrigues, V. T., Barberena, F. F. V. A., Fraga, C. N., Pessoa, E. M., Forster, W., Menini Neto, L., Furtado, S. G., Nardy, C., Azevedo, C.O. \& Guimarães, L. R. S. (2016). Orchidaceae. In: Lista de Espécies da Flora do Brasil. Jardim Botânico do Rio de Janeiro. Available in: http://floradobrasil.jbrj.gov.br/ jabot/floradobrasil/FB11958 Accessed on: 27 Jan. 2016

Chiron, G. R. (2012). Pabstiella pterophora Chiron, comb. nov. In: G. R. Chiron, J. Guiard, J. \& C. van den Berg, Phylogenetic relationships in Brazilian Pleurothallis sensu lato (Pleurothallidinae, Orchidaceae): evidence from nuclear ITS rDNA sequences. Phytotaxa 46, 55. http://dx.doi.org/10.11646/phytotaxa.46.1.5

Chiron, G. R., Guiard, J. \& van den Berg, C. (2012). Phylogenetic relationships in Brazilian Pleurothallis sensu lato (Pleurothallidinae, Orchidaceae): evidence from nuclear ITS rDNA sequences. Phytotaxa 46, 3458. http://dx.doi.org/10.11646/phytotaxa.46.1.5

Chiron, G. R. \& van den Berg, C. (2013). 2117. Proposal to conserve the name Pabstiella against Phloeophila (Orchidaceae). Taxon 62(1), 176-177.

Chiron, G. R., Karremans, A. P. \& van den Berg, C. (2016). Nomenclatural notes in the Pleurothallidinae (Orchidaceae): Phloeophila. Phytotaxa 270 (1), 56-62. http://dx.doi.org/10.11646/phytotaxa.270.1.6

Christenson, E. A. (1994). Significant collections of Orchidaceae conserved in Herbarium Hamburgense (HBG). Brittonia 46(4), 344-354. http://dx.doi. org $/ 10.2307 / 2806920$

Cogniaux, A. (1896). Orchidaceae. Flora Brasiliensis 3(4), 583-584.

Cogniaux, A. (1907). Notes sur les Orchidées du Brésil et des régions voisines. Bulletin de la Société Royale de Botanique de Belgique 43, 266-356.

Karremans, A. P., Bakker, F. T., Pupulin, F., SolanoGómez, R. \& Smulders, M. J. M. (2013). Phylogenetics of Stelis and closely related genera (Orchidaceae: Pleurothallidinae). Plant Systematics and Evolution 29, 69-86. http://dx.doi.org/10.1007/s00606-012-0712-7

Luer, C. A. (2006). Icones Pleurothallidinarum XXVIII. A reconsideration of Masdevallia; Systematics of Specklinia and vegetatively similar genera (Orchidaceae): Pabstiella. Monographs in Systematic Botany from the Missouri Botanical Garden 105, 139-143.

Luer, C. A. (2007). Icones Pleurothallidinarum XXIX. A third century of Stelis of Ecuador; Systematics of Apoda-Prorepentia; Systematics of miscellaneous small genera, addenda: new genera, species and combinations (Orchidaceae). Monographs in Systematic Botany from the Missouri Botanical Garden 112, 118-121.

Porsh, O. (1906). Orchidaceae. In: R. V. Wettstein (Ed.), Ergebnisse der Botanischen Expedition der Kaiserlichen Akademie der Wissenschaften nach Südbrasilien 1901. Band I, Pterydophyta und Antophyta. (pp. 1-75, pl. 9-18). Wien: Aus der Kaiserlich - Königlichen Hof Und Staatsdruckerei.

Pridgeon, A. M. (2005). Pabstiella. In: A. M. Pridgeon, P. J. Cribb, M. W. Chase \& F. N. Rasmussen (Eds.), Genera Orchidacearum, 4. Epidendroideae, Part One (pp. 378381). Oxford, Oxford University,

Pridgeon, A. M. \& Chase, M. W. (2001). A phylogenetic reclassification of Pleurothallidinae (Orchidaceae). Lindleyana 16, 235-271.

Reichenbach, H. G. (1878). Pleurothallis leucopyramis. Xenia Orchidaceae 3(1), 14-15, pl. 210, fig. I, 1-9.

Reichenbach, H. G. (1881). Novitiae Orchidaceae Warmingianae. Otia Botanica Hamburgensia 2(1), 78-95. 

Toscano de Brito, A. L. V. \& Luer, C. A. (2013).
Reconsideration of Pabstiella pleurothalloides and description of Pabstiella varellae, a new species confused with Pabstiella campestris (Pleurothallidinae: Orchidaceae). Harvard Papers in Botany 18(2), 241257.

Veitch, J. (1889). Manual of orchidaceous plants cultivated under glass in Great Britain, volume 1, part 10 (pp. 3-4). London, H. M. Pollett \& Co.
Warming, E. (1884). Symbolae ad floram Brasiliae centralis cognoscendam, particula XXIX, Orchideae (manipulus primus) (pp. 351-358). Kjøbenhavn, Bianco Lunos Kgl. Hof-Bogtrykkeri.

WCSP (2016). World Checklist of Selected Plant Families. Facilitated by the Royal Botanic Gardens, Kew. Published on the Internet; http://apps.kew.org/wcsp/ 
